\title{
Statistical Optimisation of Diesel Biodegradation at Low Temperatures by an Antarctic Marine Bacterial Consortium Isolated from Non-Contaminated Seawater
}

\author{
Nur Nadhirah Zakaria ${ }^{1}$, Claudio Gomez-Fuentes $\left.{ }^{2,3}{ }^{(}\right)$, Khalilah Abdul Khali1 ${ }^{4}$, Peter Convey ${ }^{5,6}{ }^{(}$, \\ Ahmad Fareez Ahmad Roslee ${ }^{1}$, Azham Zulkharnain ${ }^{7}{ }^{D}$, Suriana Sabri ${ }^{8}{ }^{\mathbb{D}}$, Noor Azmi Shaharuddin ${ }^{1}$, \\ Leyla Cárdenas 9 and Siti Aqlima Ahmad 1,3,10,*iD
}

1 Department of Biochemistry, Faculty of Biotechnology and Biomolecular Sciences, Universiti Putra Malaysia, Serdang 43400, Selangor, Malaysia; nadhirahairakaz@gmail.com (N.N.Z.); fareezlee@yahoo.com (A.F.A.R.); noorazmi@upm.edu.my (N.A.S.)

2 Department of Chemical Engineering, Universidad de Magallanes, Avda. Bulnes,

Punta Arenas 01855, Región de Magallanes y Antártica Chilena, Chile; claudio.gomez@umag.cl

3 Center for Research and Antarctic Environmental Monitoring (CIMAA), Universidad de Magallanes, Avda. Bulnes, Punta Arenas 01855, Región de Magallanes y Antártica Chilena, Chile

4 School of Biology, Faculty of Applied Sciences, Universiti Teknologi MARA, Shah Alam 40450, Selangor, Malaysia; khali552@uitm.edu.my

check for updates

Citation: Zakaria, N.N.; GomezFuentes, C.; Abdul Khalil, K.; Convey, P.; Roslee, A.F.A.; Zulkharnain, A.; Sabri, S.; Shaharuddin, N.A.; Cárdenas, L.; Ahmad, S.A. Statistical Optimisation of Diesel Biodegradation at Low Temperatures by an Antarctic Marine Bacterial Consortium Isolated from Non-Contaminated Seawater. Microorganisms 2021, 9, 1213. https://doi.org/10.3390/ microorganisms 9061213

Academic Editor: Jaak Truu

Received: 14 April 2021 Accepted: 31 May 2021 Published: 3 June 2021

Publisher's Note: MDPI stays neutral with regard to jurisdictional claims in published maps and institutional affiliations.

Copyright: (C) 2021 by the authors. Licensee MDPI, Basel, Switzerland. This article is an open access article distributed under the terms and conditions of the Creative Commons Attribution (CC BY) license (https:/ / creativecommons.org/licenses/by/ $4.0 /)$.
5 British Antarctic Survey, NERC, High Cross, Madingley Road, Cambridge CB3 0ET, UK; pcon@bas.ac.uk

6 Department of Zoology, University of Johannesburg, PO Box 524, Auckland Park 2006, South Africa

7 Department of Bioscience and Engineering, College of Systems Engineering and Science, Shibaura Institute of Technology, 307 Fukasaku, Minumaku, Saitama 337-8570, Japan; azham@shibaura-it.ac.jp

8 Department of Microbiology, Faculty of Biotechnology and Biomolecular Sciences, Universiti Putra Malaysia, Serdang 43400, Selangor, Malaysia; suriana@upm.edu.my

9 Centro Fondap Ideal, Insituto de Ciencias Ambientales y Evolutivas, Facultad de Ciencias, Universidad Austral de Chile, Casilla 567, Valdivia, Chile; leylacardenas@uach.cl

10 National Antarctic Research Centre, B303 Level 3, Block B, IPS Building, Universiti Malaya, Kuala Lumpur 50603, Malaysia

* Correspondence: aqlima@upm.edu.my

Abstract: Hydrocarbon pollution is widespread around the globe and, even in the remoteness of Antarctica, the impacts of hydrocarbons from anthropogenic sources are still apparent. Antarctica's chronically cold temperatures and other extreme environmental conditions reduce the rates of biological processes, including the biodegradation of pollutants. However, the native Antarctic microbial diversity provides a reservoir of cold-adapted microorganisms, some of which have the potential for biodegradation. This study evaluated the diesel hydrocarbon-degrading ability of a psychrotolerant marine bacterial consortium obtained from the coast of the north-west Antarctic Peninsula. The consortium's growth conditions were optimised using one-factor-at-a-time (OFAT) and statistical response surface methodology (RSM), which identified optimal growth conditions of $\mathrm{pH} 8.0,10{ }^{\circ} \mathrm{C}, 25 \mathrm{ppt} \mathrm{NaCl}$ and $1.5 \mathrm{~g} / \mathrm{L} \mathrm{NH}_{4} \mathrm{NO}_{3}$. The predicted model was highly significant and confirmed that the parameters' salinity, temperature, nitrogen concentration and initial diesel concentration significantly influenced diesel biodegradation. Using the optimised values generated by RSM, a mass reduction of $12.23 \mathrm{mg} / \mathrm{mL}$ from the initial $30.518 \mathrm{mg} / \mathrm{mL}(4 \%(w / v))$ concentration of diesel was achieved within a $6 \mathrm{~d}$ incubation period. This study provides further evidence for the presence of native hydrocarbon-degrading bacteria in non-contaminated Antarctic seawater.

Keywords: Antarctica; biodegradation; diesel; microbial consortium; seawater

\section{Introduction}

Antarctica is administered under the Antarctic Treaty, which came into force in 1961 and currently includes 54 member states (known as Parties), 29 of which are full 'Consultative Parties', which participate in consensus decision making at the annual Antarctic Treaty 
Consultative Meetings. During the Treaty's existence, various environmental regulations have been adopted and enforced to protect and preserve the natural environment of Antarctica. Human activity in Antarctica carries environmental risks associated with using fossil fuels, which are relied upon heavily as the primary energy source for powering research stations, as well as vessels, vehicles and aircraft [1]. Despite this, oil spills have occurred throughout the life of the Treaty, affecting all major types of the Antarctic environment (marine, terrestrial, ice) [2-5]. Small-scale spills have been reported mostly in the vicinity of research stations, the majority of which lie near the coastline and field camps [6], with (much) larger spills associated with shipping accidents, station refueling and air operations $[4,7,8]$. Many research stations confirm their reliance on diesel fuel [9-11]. Although precise figures are difficult to obtain, in 2004, annual fuel consumption reported by research stations amounted to 90 million litres, $75 \%$ of which was diesel fuel [1].

Despite the scale of current and predicted future shipping operations using the 'northern sea route' in the Arctic Ocean as multi-year sea ice extent rapidly decreases, the existence of large-scale hydrocarbon extraction industries both on land and in the marine environment of the Arctic (and associated history of very large-scale spills, including major shipping accidents involving supertankers), the repercussions of hydrocarbon pollution in Antarctica are potentially more significant than in the northern polar regions. This is due to Antarctica's greater isolation, the general lack of large-scale response facilities and logistics and the distances required to deliver needed equipment and personnel to any spill location. The sources of hydrocarbons related to anthropogenic activities in Antarctica include fossil fuel combustion, fuel storage, accidental oil spills and sewage discharge [12-15]. Shipping accidents and the ship-to-shore refuelling activities necessary for the running of Antarctic programs have proven to be the most hazardous activities, as they can potentially lead to very large spills affecting both marine and terrestrial environments [10,16]. Hydrocarbon pollution is both long-lived and pervasive in Antarctica [17]. Hydrocarbons detected in surface waters of Antarctica have been traced to melt from pack-ice, permafrost and continental ice and snow, originating from atmospheric deposition [18].

The initial impact of hydrocarbons spilled into marine waters occurs near the sea's surface, rather than in the underlying water column [19]. Obligate hydrocarbonoclastic bacteria (OHCB) are recognised for their ability to utilise hydrocarbons almost exclusively as a sole carbon source, with the added significance of being found in many marine environments [20]. Species related to OHCB have been reported in the pristine waters of Antarctica [21-23]. OHCB are regarded as key players in the natural cleansing of oil-polluted marine systems [22]. OHCB species have also been reported to utilise the well-known intermediate metabolites of hydrocarbons, pyruvate and pyruvic acid, as a carbon source [24].

Native microbial consortia that are present in marine environments are likely to degrade the major fractions of hydrocarbon pollutants, ultimately reducing the impact of oil spills [25]. However, the impact of hydrocarbon pollution even at a very local scale in Antarctica is magnified because of the combination of Antarctica's largely pristine environment and its sensitive and often endemic biological communities [26]. In marine ecosystems, even small-scale oil spills can result in toxic dissolved compounds becoming bioavailable [27]. It has long been recognised that hydrocarbons, including polyaromatic hydrocarbons, are able to support microbial growth [28] and microbial biodegradation is increasingly widely accepted as a primary dissipation mechanism for most organic pollutants $[25,29]$. However, under the terms of the Protocol for Environmental Protection to the Antarctic Treaty, the introduction of non-native organisms to the natural environment of Antarctica is prohibited, as is the use of many classes of chemicals that might themselves cause damage to the environment. Thus, any application of bioremediation approaches in Antarctica requires the identification and use of native microbial species or consortia.

Microbial remediation technology can make a key contribution to ecological security when dealing with petroleum hydrocarbon-polluted environments, due to its relatively low cost and minimal environmental impact [30]. Technologies that exploit progressively 
more effective strains of microbes have been developed over time, including some broadspectrum hydrocarbon-degrading bacteria [31,32]. However, no single bacteria can degrade the entire petroleum hydrocarbon spectrum in isolation. In recent years, considerable effort has been devoted to exploiting marine organisms in the bioremediation of pollutants [33]. Extensive studies of hydrocarbon biodegradation by cold-adapted single strains of marine bacteria have been explored [22,23,34].

Studies have indicated that biodegradation potential could be improved through the application of bacterial consortia (i.e., combinations of multiple species/strains). Such consortia can offer more diverse catabolic genes and their synergistic effects may be beneficial in achieving more efficient mineralisation of pollutants [35]. Consortia have yielded better results in both aliphatic and polyaromatic chain hydrocarbon degradation [36], and have also increasingly addressed the population dynamics of Antarctic marine microbial communities under exposure to hydrocarbons [4,37-39]. However, there remains a lack of consortium studies based on the native microbiota of Antarctic seawater, despite some of the largest Antarctic hydrocarbon pollution events taking place in the marine environment [16].

The effectiveness of bioremediation technology applications for petroleum hydrocarbon pollution is increasing [40] and increasing interest is being shown in its use in Antarctica [41,42]. Bioremediation applications need to be designed in a site-specific manner and be based on detailed knowledge of the local native microbial communities and their responses to exposure to contaminants [43].

Studies aimed at enhancing the biodegradation of diesel have used optimisation approaches through multivariate statistical techniques, such as response surface methodology (RSM). RSM includes a series of statistically designed experiments that can effectively minimise error in determining the effects of parameters and their interactions and can be used to determine the optimum conditions required to maximise biodegradation [42,44]. With this background, the current study sets out to assess the ability of a native bacterial consortium obtained from unpolluted Antarctic seawater to effectively biodegrade diesel using RSM.

\section{Materials and Methods}

\subsection{Sampling and Media}

Seawater samples were collected from the coast close to the Chilean research station, General Bernardo O'Higgins on the Trinity Peninsula, north-west Antarctic Peninsula $\left(63^{\circ} 19^{\prime} 15^{\prime \prime} \mathrm{S} 57^{\circ} 53^{\prime} 55^{\prime \prime} \mathrm{W}\right)$. Samples were collected during 2 successive austral summers in December-January 2017/18 and 2018/19. Water samples (50 mL) were obtained between 0-15 m depth using sterile polycarbonate bottles and were kept at $4{ }^{\circ} \mathrm{C}$ until processing. After being rapidly returned to the laboratory, the samples were divided into $2 \mathrm{~mL}$ aliquots and immediately frozen at $-80^{\circ} \mathrm{C}$ until required.

All chemicals used were of analytical grade unless otherwise specified. Petronas diesel, locally obtained from a fuel station in Selangor, Malaysia, was used as the sole carbon source in the screening and optimisation part of this study. The diesel was filtered using a sterile $0.22 \mu \mathrm{m}$ pore size filter syringe and stored at room temperature $\left(25^{\circ} \mathrm{C}\right)$ in a sterile, amber glass Schott bottle to avoid photooxidation [42].

\subsection{Screening for Diesel Hydrocarbon Biodegradation}

One millilitre of each water sample was precultured into nutrient broth and incubated at $10{ }^{\circ} \mathrm{C}$ to obtain the initial bacterial consortia. Precultured samples were incubated until visible cell turbidity appeared (48-144 h) before being centrifuged at $8000 \times$ rpm for $10 \mathrm{~min}$, and the resulting pellets were washed once using $1 \times$ phosphate-buffered saline (PBS: $137 \mathrm{mM} \mathrm{NaCl}, 2.7 \mathrm{mM} \mathrm{KCl}$ in $10 \mathrm{mM}$ phosphate buffer, $\mathrm{pH}$ 7.4). The pellets were re-suspended in PBS to an absorbance reading of $\mathrm{OD}_{600}=1.0$, which yielded a CFU $/ \mathrm{mL}$ of $38 \times 10^{20}$. Preparation of bacterial suspension followed this procedure throughout the study except when indicated otherwise. Diesel degrading abilities of the samples were 
assessed using a standardised Bushnell-Haas (BH) salt medium [45]. This was adjusted to $\mathrm{pH}$ 7.0, further supplemented with $20 \mathrm{~g} \mathrm{NaCl}(w / v)$, equivalent to $20 \mathrm{ppt}$ salinity, and 1.0\% $(v / v)$ initial diesel fuel concentration added as the sole carbon source. All experiments were performed in triplicate in an overall volume of $50 \mathrm{~mL}$ in flasks. Flasks without inoculum served as controls to assess any abiotic degradation of the diesel. Selection of the bacterial consortium to be used in the subsequent parts of the study was based on the combination of degree of diesel degradation achieved and growth rate.

\subsection{Optimisation of Diesel Degradation Using One-Factor-at-a-Time (OFAT)}

Diesel degradation was first studied using the OFAT approach by optimising the growth conditions of the selected Antarctic marine bacterial consortium. The parameters optimised were $\mathrm{pH}$, salinity, temperature, nitrogen source and concentration and initial substrate (diesel) concentration. Each parameter was optimised in $50 \mathrm{~mL} \mathrm{BH}$ media on an orbital shaker $(150 \mathrm{rpm})$ at $10{ }^{\circ} \mathrm{C}$ (the temperature was optimised separately) (Table 1 ). After a $7 \mathrm{~d}$ incubation period, $1 \mathrm{~mL}$ from each flask was centrifuged at 13,000× rpm for 10 min to yield an inoculum cell pellet. Growth was measured using suspension turbidity as a proxy, using a UV-Vis spectrophotometer and a wavelength of $600 \mathrm{~nm}\left(\mathrm{OD}_{600}\right)$.

Table 1. Parameters used and their ranges used in the OFAT experiment.

\begin{tabular}{cc}
\hline Parameter & Range \\
\hline $\mathrm{pH}$ (potassium phosphate and Tris buffer) & $5.2-9.0$ \\
Salinity, $\mathrm{NaCl}(\mathrm{ppt}, w / v)$ & $0-50$ \\
Temperature $\left({ }^{\circ} \mathrm{C}\right)$ & $10-25$ \\
Nitrogen source & urea, $\mathrm{NH}_{4} \mathrm{NO}_{3}, \mathrm{NaNO}_{3}, \mathrm{KNO}_{3}, \mathrm{NH}_{4} \mathrm{SO}_{4}$ \\
Nitrogen concentration, $\mathrm{g} / \mathrm{L}(w / v)$ & $0-3.5$ \\
Initial substrate concentration, diesel $(\%, v / v)$ & $0.5-5.0$ \\
\hline
\end{tabular}

Bushnell-Haas (BH) salt medium was supplemented with diesel at $1.0 \%(v / v)$ except in the final step of optimising initial substrate concentration. Each parameter was optimised successively in the order listed in Table 1. One-way ANOVA was used to test the influence of each parameter on microbial growth and percentage of diesel degradation followed, where significant, by pairwise post hoc comparisons using Tukey's test.

\subsection{Quantification of Diesel Degradation}

Residual diesel mass was measured gravimetrically using n-hexane extraction [46]. At the end of the incubation period, the remaining diesel in each triplicate flask was extracted using $20 \mathrm{~mL}$ of n-hexane, which was then agitated for $60 \mathrm{~min}$ at a room temperature of $25{ }^{\circ} \mathrm{C}$. The extraction yielded two layers and the upper organic layer was removed into a glass Petri dish and the solvent evaporated in a fume hood. The percentage of diesel degradation (\%) was calculated using Equation (1) [47]. Abiotic control values were subtracted from the residual mass to calculate biodegradation [48].

$$
\begin{gathered}
\% \text { Biodegradation }= \\
\frac{[\text { Mass of resdidual diesel abiotic control }(\mathrm{g})-\text { Mass of residual diesel treatment }(\mathrm{g})]}{\text { Mass ofdiesel in abiotic control }(\mathrm{g})} \times 100
\end{gathered}
$$

\subsection{Response Surface Methodology}

Response Surface Methodology is a combination of statistical and mathematical methods that are used to generate a sequence of design experiments that minimises the number of experimental runs required to achieve the desired results. Importantly, unlike OFAT, this methodology allows for the identification of significant pairwise interactions between the tested parameters influencing diesel degradation. Two experimental designs (DoE) were applied in this study, Placket-Burman design (PBD) and Central Composite Design (CCD). Both DoE approaches were analysed using Design-Expert version 12 (Stat Ease, Inc, Minneapolis, MN, USA). The adequacy of the model terms was assessed using analysis of 
variance (ANOVA). The significance of each model term, also labelled as a coefficient in the equation, was determined by Fisher's F test and (ANOVA). Probability values $<0.05$ are accepted as being significant. Adeq precision measures the signal to noise ratio, and a ratio greater than 4 is desirable. Low coefficient of variation values (CV) support the precision and reliability of the model. $\mathrm{R}^{2}$ measures the goodness of fit of the values obtained.

\subsubsection{Selection of Significant Variables by Plackett-Burman Design}

Generally, a Plackett-Burman (PB) design is used to rapidly screen multiple factors to discover the significant independent parameters [49,50]. PBD is useful for economically detecting large main effects by independent parameters assuming that any factor interactions remain negligible compared with the main effects. The factors previously determined in OFAT were further screened using PB factorial design with a first-order polynomial equation. Each factor was tested at high $(+1)$ and low $(-1)$ levels (Table 2). Diesel reduction was set to be the response variable of the DoE. The incubation period for PBD runs was $7 \mathrm{~d}$, as used in OFAT.

Table 2. Experimental values and levels of variables tested for bacterial consortium in PlackettBurman design.

\begin{tabular}{ccccc}
\hline Variables & Code & Unit & \multicolumn{2}{c}{ Experimental Range } \\
\hline & & & Low (-1) & High (+1) \\
\hline $\mathrm{pH}$ & $\mathrm{A}$ & - & 7.5 & 8.0 \\
Salinity & $\mathrm{B}$ & $\mathrm{ppt}$ & 25.0 & 30.0 \\
Temperature & $\mathrm{C}$ & ${ }^{\circ} \mathrm{C}$ & 10.0 & 15.0 \\
Nitrogen concentration & $\mathrm{D}$ & $\mathrm{g} / \mathrm{L}$ & 0.5 & 2.5 \\
Initial diesel concentration & $\mathrm{E}$ & $\%(v / v)$ & 1.0 & 4.0 \\
\hline
\end{tabular}

The PBD follows the first-order model below.

$$
Y=\beta_{0}+\sum_{i=1}^{k} \beta_{i} x_{i}
$$

where $Y$ represents the response variable, $x$ are the independent factors that influence $Y, \beta_{0}$ is the intercept, $k$ is the number of involved factors and $\beta_{i}$ is the ith linear coefficient.

\subsubsection{Central Composite Design}

After PBD has identified the significant single factors, RSM applies central composite design (CCD) to further optimise diesel biodegradation. The design model is quadratic and is fitted to characterise the nature of the response surface in the favoured experimental region. Table 3 lists the effects of each parameter on diesel degradation, which were studied at five different levels by combining two factorial points, two axial points and a sole central point $(+2,+1,0,-1,-2)$. The percentage of diesel degradation was again the response variable. The experimental response was fitted to a second-order polynomial regression model including the significant linear, pairwise and quadratic interaction coefficients to predict the optimal conditions. The quadratic mathematical model used is shown in Equation (3).

$$
y=\beta_{0}+\sum_{i=1}^{k} \beta_{i} x_{i}+\sum_{i=1}^{k} \beta_{i i} x_{i}^{2}+\sum_{1=i \leq j}^{k} \beta_{i j} x_{i} x_{j}, i \neq j
$$

where $y$ represents the response variable, $x$ are the independent factors that influence $\mathrm{Y}, \beta_{0}$ is the intercept, $\mathrm{k}$ is the number of involved factors, $\beta_{\mathrm{i}}$ is the ith linear coefficient, $\beta_{\mathrm{ii}}$ is the quadratic coefficient, $\beta_{\mathrm{ij}}$ the coefficient of interaction effect when $\mathrm{i}<\mathrm{j}$, with $\mathrm{i}$ and $j=1,2,3$ and $\mathrm{i} \neq \mathrm{j}$. All experiments were performed in triplicate. 
Table 3. Experimental values and levels of the selected independent factors for CCD optimisation.

\begin{tabular}{cccccccc}
\hline & \multirow{2}{*}{ Symbol } & \multirow{2}{*}{ Unit } & \multicolumn{2}{c}{ Experimental Values } & \multicolumn{1}{c}{$\mathbf{- 1}$} & $\mathbf{0}$ & $\mathbf{+ 1}$ \\
\hline Salinity & $\mathrm{A}$ & $\mathrm{ppt}$ & 22.5 & 25.0 & 27.5 & 30.0 & 32.5 \\
Temperature & $\mathrm{B}$ & $\mathrm{C}$ & 7.5 & 10.0 & 12.5 & 15.0 & 17.5 \\
Nitrogen concentration & $\mathrm{C}$ & $(\mathrm{g} / \mathrm{L})$ & 0.0 & 0.5 & 1.0 & 1.5 & 2.0 \\
Initial diesel concentration & $\mathrm{D}$ & $\%(\mathrm{v} / \mathrm{v})$ & 0 & 1.0 & 2.5 & 4.0 & 5.5 \\
\hline
\end{tabular}

\section{Results}

\subsection{Screening of Diesel Degrading Consortia}

A $7 \mathrm{~d}$ incubation period was used for all samples to identify the existence of hydrocarbon degrading ability, with samples shown separately according to the sampling season in Figure 1.
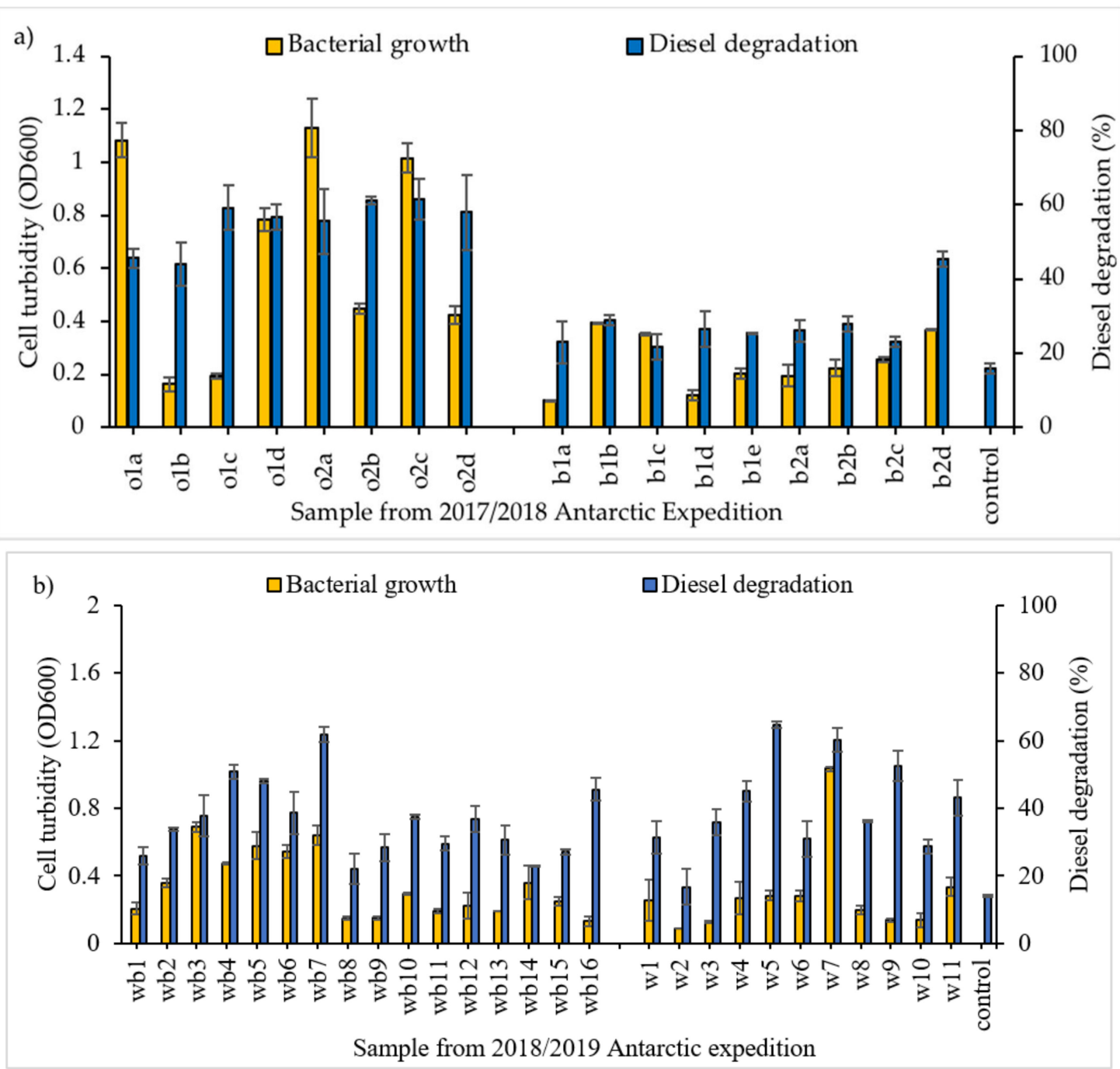

Figure 1. Screening of bacterial consortia growth and diesel degradation obtained from Antarctic seawater samples collected in (a) 2017/18 and (b) 2018/19; all consortia grown in BH media, supplemented with $20 \mathrm{ppt} \mathrm{NaCl}$ and $1.0 \%$ initial diesel concentration as sole carbon source. Vertical bars indicate SEM of three replicates.

Among the samples tested, the consortium obtained from sample $\mathrm{o} 2 \mathrm{~b}$ displayed the highest level of diesel degradation $(77.97 \% \pm 2.24)$, although comparable to consortia o1a, $\mathrm{o} 2 \mathrm{a}$ and $\mathrm{o} 2 \mathrm{c}$. As consortium $\mathrm{o} 2 \mathrm{~b}$ showed high degradation abilities with considerably lower 
growth, it was selected for further study. This sample was obtained close to the coast of Kopaitic Island (Figure 2).

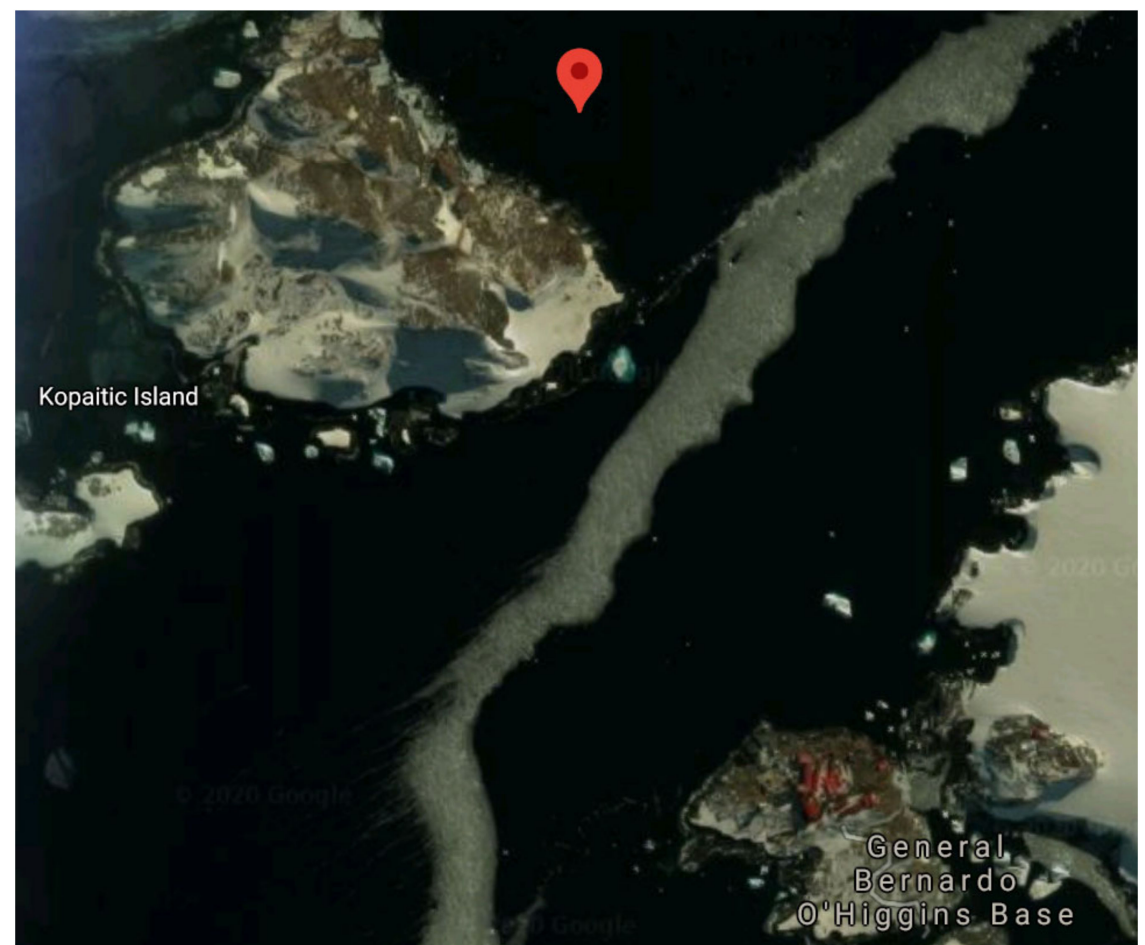

Figure 2. Aerial photograph showing source location of selected consortium sample. (Source: Google.com).

\subsection{Optimisation of Growth Conditions Using Conventional One-Factor-at-a-Time}

\subsubsection{Effect of $\mathrm{pH}$, Salinity and Temperature on Diesel Degradation}

Analysis of variance (ANOVA) was used to assess the influence of the variables tested on bacterial consortium growth and diesel biodegradation. This identified a significant effect of $\mathrm{pH}$ on diesel degradation $\left(\mathrm{F}_{11,24}=4.851, p=0.0006\right)$. Tukey's post hoc tests revealed significant differences between $\mathrm{pH} 5.8$ and $8.0(p=0.019)$ and $\mathrm{pH} 6.5$ and 8.0 in the phosphate buffer system $(p=0.0002)$ but no significant differences in the range of $\mathrm{pH}$ 7.0-8.5. Degradation achieved at $\mathrm{pH} 8.0$ and 9.0 was significantly different $(p=0.0108)$. Consortium $\mathrm{o} 2 \mathrm{~b}$ showed maximum growth at $\mathrm{pH} 7.0$ but maximum diesel degradation at $\mathrm{pH} 7.5$ and 8.0 in phosphate buffer, with performance in Tris buffer being slightly better at $\mathrm{pH}$ 8.0. The differences in $\mathrm{pH}$ also had a significant influence on growth of consortium $\mathrm{o} 2 \mathrm{~b}$ $\left(\mathrm{F}_{10,22}=15.70, p=0.0003\right)$. Tukey's post hoc comparisons revealed no significant differences between $\mathrm{pH} 7.0-\mathrm{pH} 8.0$ for the phosphate buffer. Growth at $\mathrm{pH} 8.0$ in both phosphate and Tris buffer systems was also not significantly different. However, growth at $\mathrm{pH} 7.5$ in phosphate and Tris buffer systems was significantly different $(p<0.0029)$.

ANOVA confirmed that salinity had a significant influence on diesel degradation by bacterial consortium $\mathrm{o} 2 \mathrm{~b}\left(\mathrm{~F}_{8,10}=5.238, p=0.0149\right)$. Optimal diesel degradation and bacterial growth were achieved at a salinity of $30 \mathrm{ppt}$ (Figure 3b). Tukey's post hoc comparisons revealed significant differences in degradation between $0 \mathrm{ppt}$ and $30 \mathrm{ppt}$ $(p=0.005)$ and between 30 and $40 \mathrm{ppt}(p=0.0149)$. Consortium growth generally increased with salinity, with ANOVA confirming a significant influence of salinity on growth $\left.\mathrm{F}_{9,20}=21.39, p<0.0001\right)$. At $35 \mathrm{ppt}$ and $40 \mathrm{ppt}$, consortium growth was lower but not significantly different to $30 \mathrm{ppt}$, as was the degradation of diesel achieved. Tukey's post hoc comparisons revealed significant differences between $30 \mathrm{ppt}$ and all other lower salinities. 

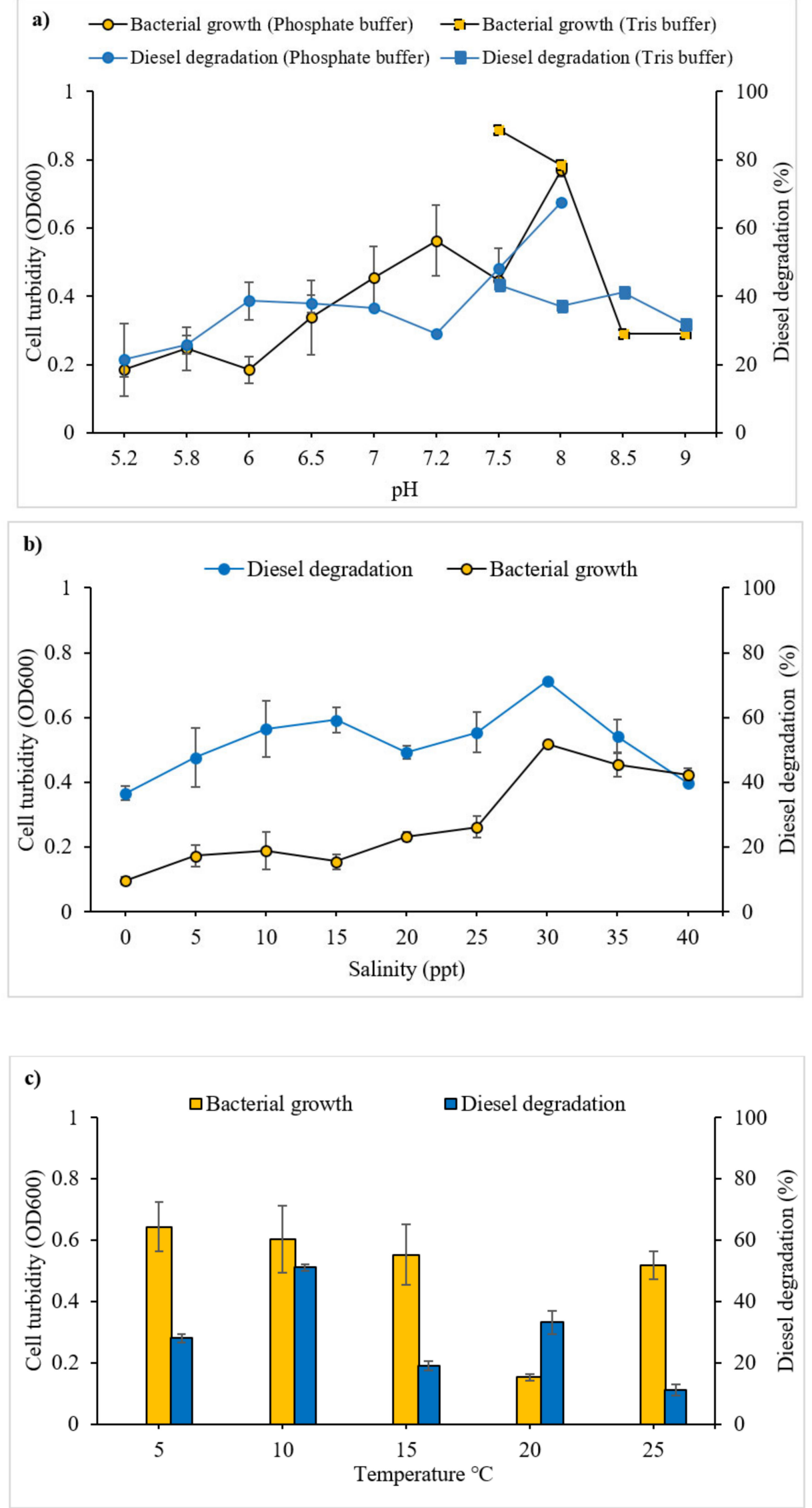

Figure 3. Effect of (a) varying $\mathrm{pH}$ (using two buffer systems), (b) salinity (\% $w / v$ ) and (c) temperature on bacterial consortium growth and diesel degradation. Vertical bars indicate SEM of three replicates. 
Temperature also significantly influenced diesel degradation (Figure $3 \mathrm{c})\left(\mathrm{F}_{4,10}=78.66\right.$, $p<0.0001)$ and microbial growth $\left(\mathrm{F}_{4,9}=19.30, p=0.0002\right)$. All post hoc pairwise temperature comparisons on diesel biodegradation were significant (all $p<0.0001$ ). Post hoc comparisons revealed no significant influence of temperature on microbial growth between $5^{\circ} \mathrm{C}$ and $10^{\circ} \mathrm{C}, 10^{\circ} \mathrm{C}$ and $15^{\circ} \mathrm{C}$ and $10^{\circ} \mathrm{C}$ and $25^{\circ} \mathrm{C}$. However, higher temperatures, such as $20^{\circ} \mathrm{C}$, led to significant reduction in growth compared to the optimum temperature for growth of $10^{\circ} \mathrm{C}(p=0.0001)$.

\subsubsection{Effect of Nitrogen Source and Concentration on Diesel Degradation}

Figure 4 a displays the effects of different nitrogen sources on bacterial growth and degradation of diesel. There were overall significant differences in the influence of the different nitrogen sources on diesel degradation and microbial growth $\left(\mathrm{F}_{5,12}=20.5, p<0.0001\right)$. Post hoc tests identified no significant differences in diesel degradation between the nitrogen sources $\mathrm{NH}_{4} \mathrm{NO}_{3}, \mathrm{NH}_{4} \mathrm{Cl}, \mathrm{NH}_{4} \mathrm{SO}_{4}$ and urea. A significant difference in consortium growth was identified between $\mathrm{NH}_{4} \mathrm{NO}_{3}$ and urea $(p=0.0001)$. Based on achieving the greatest degradation, ammonium nitrate $\left(\mathrm{NH}_{4} \mathrm{NO}_{3}\right)$ was selected as the nitrogen source for further optimisation.
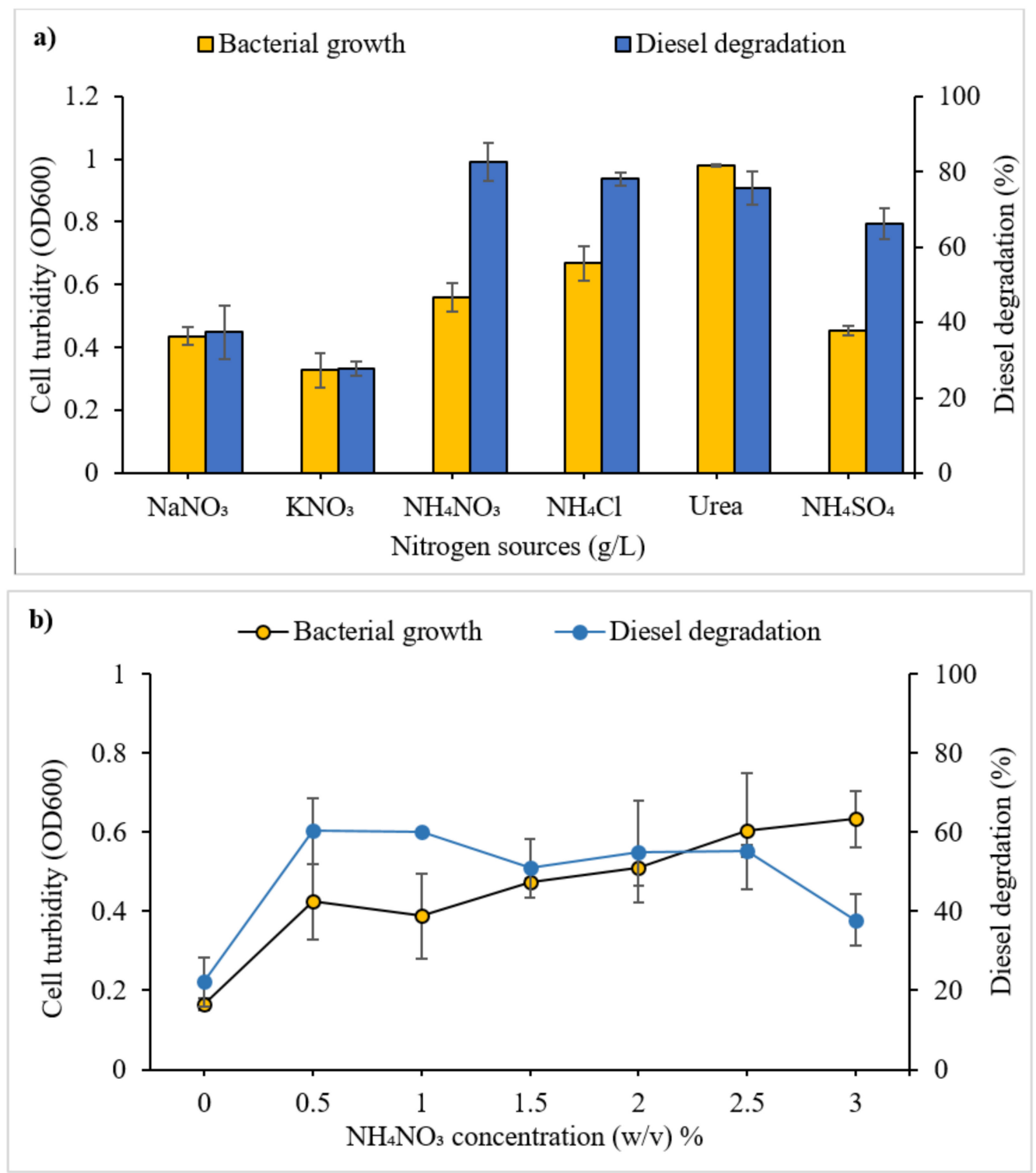

Figure 4. Effects of (a) different nitrogen sources and (b) of the selected nitrogen source concentration on bacterial consortium growth and diesel degradation. Vertical bars indicate SEM of three replicates. 
The influence of $\mathrm{NH}_{4} \mathrm{NO}_{3}$ concentration on microbial growth and diesel degradation is shown in Figure $4 \mathrm{~b}$. Growth and degradation differed significantly between $\mathrm{NH}_{4} \mathrm{NO}_{3}$ concentrations $\left(\mathrm{F}_{6,14}=4.884, p=0.0068\right.$ and $\mathrm{F}_{6,14}=3.092, p=0.0383$, respectively $)$. Maximum degradation was observed at $0.5-1.0 \mathrm{~g} / \mathrm{L}$ (although not differing significantly up to $2.5 \mathrm{~g} / \mathrm{L}$ ). Tukey's post hoc comparison revealed that diesel degradation did not differ significantly across all nitrogen concentrations tested. Bacterial growth increased with an increasing concentration of ammonium nitrate. Tukey's post hoc comparisons revealed no significant differences in the influence of nitrogen concentration on consortium growth between values 0 and $2.0 \mathrm{~g} / \mathrm{L}$. Growth was significantly greater at nitrogen concentrations of $2.5 \mathrm{~g} / \mathrm{L}(p=0.0033)$ and $3.0 \mathrm{~g} / \mathrm{L}(p=0.0197)$ compared to $0.0 \mathrm{~g} / \mathrm{L}$, but did not differ significantly between them.

\subsubsection{Effect of Initial Diesel Concentration on Bacterial Consortium Growth and Diesel Degradation}

The initial diesel concentration significantly influenced both bacterial consortium growth $\left(\mathrm{F}_{8,18}=17.64, p<0.0001\right)$ and diesel degradation $\left(\mathrm{F}_{8,18}=173.7, p<0.0001\right)$ (Figure 5). Post hoc comparisons indicated that increasing initial diesel concentration had a significant effect on the absolute amount of diesel that was degraded up to a concentration of $3.5 \%$. However, further increase to $4.0,4.5$ or $5.0 \%$ did not lead to any further increase in diesel degradation, and $5.5 \%$ led to a considerable decrease in degradation. Bacterial consortium growth generally increased with increasing initial diesel concentration up to $4 \%$.

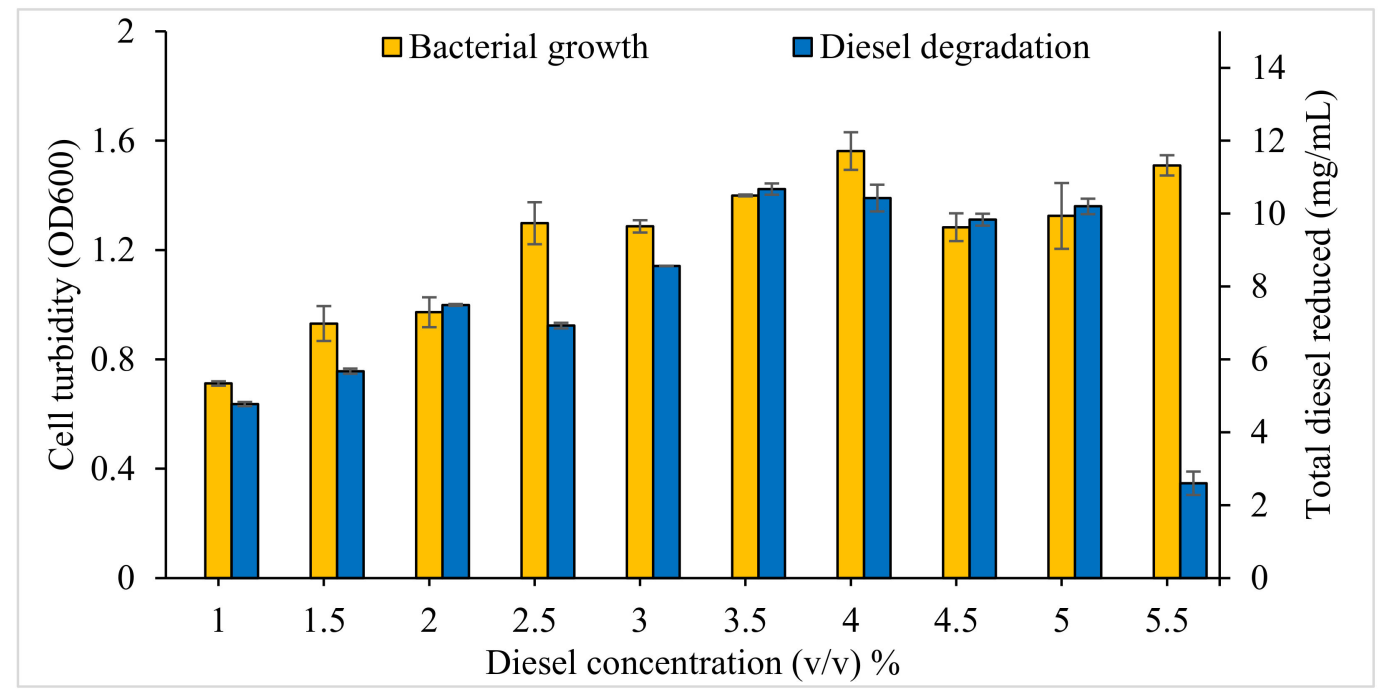

Figure 5. Effects of initial diesel concentration $(v / v)$ on bacterial consortium o2b growth and diesel degradation. Vertical bars indicate SEM of three replicates.

\subsection{Application of Response Surface Methodology in the Selection of Significant Variables 3.3.1. Plackett-Burman Design}

The PB design matrix was applied to bacterial consortium o2b. Twelve runs were generated (Table 4). Across these runs diesel degradation ranged between $16.58 \%$ and $39.35 \%$. The highest value (run 10) was obtained at a temperature of $15^{\circ} \mathrm{C}, \mathrm{pH} 8.0,25 \mathrm{ppt}$ salinity, $0.5 \mathrm{~g} / \mathrm{L} \mathrm{NH}_{3} \mathrm{NO}_{4}$ and $1.0 \%$ diesel and the lowest (run 4 ) at $10{ }^{\circ} \mathrm{C}, \mathrm{pH} 7.5,25 \mathrm{ppt}$ salinity, $2.5 \mathrm{~g} / \mathrm{L} \mathrm{NH}_{3} \mathrm{NO}_{4}$ and $4.0 \%$ diesel. Most other PBD runs at a temperature of $15{ }^{\circ} \mathrm{C}$ also gave high diesel biodegradation outcomes (Table 4).

ANOVA identified the parameters that significantly influenced diesel degradation by bacterial consortium $\mathrm{o} 2 \mathrm{~b}$, with the only factor not having a significant influence being $\mathrm{A}$ $(\mathrm{pH})$, and also confirmed that the overall model was highly significant (Table 5). 
Table 4. Secondary screening of significant parameters affecting diesel degradation using PlackettBurman design matrix for bacterial consortium o2b $( \pm \mathrm{SEM}, n=3)$.

\begin{tabular}{ccccccc}
\hline Run & A & B & C & D & E & $\begin{array}{c}\text { Degradation } \\
(\mathbf{m g} / \mathbf{m L})\end{array}$ \\
\hline 1 & 8.0 & 30.0 & 15.0 & 0.5 & 30.51 & $9.62 \pm 1.54$ \\
2 & 7.5 & 25.0 & 15.0 & 2.5 & 30.51 & $5.76 \pm 2.51$ \\
3 & 8.0 & 30.0 & 10.0 & 2.5 & 30.51 & $5.17 \pm 0.37$ \\
4 & 7.5 & 25.0 & 10.0 & 2.5 & 30.51 & $5.06 \pm 1.06$ \\
5 & 7.5 & 30.0 & 15.0 & 2.5 & 7.69 & $2.34 \pm 2.24$ \\
6 & 8.0 & 30.0 & 10.0 & 2.5 & 7.69 & $2.05 \pm 1.01$ \\
7 & 8.0 & 25.0 & 15.0 & 2.5 & 7.69 & $2.10 \pm 1.99$ \\
8 & 8.0 & 25.0 & 10.0 & 0.5 & 30.51 & $8.03 \pm 1.98$ \\
9 & 7.5 & 30.0 & 10.0 & 0.5 & 7.69 & $2.85 \pm 8.17$ \\
10 & 8.0 & 25.0 & 15.0 & 0.5 & 7.69 & $3.13 \pm 1.37$ \\
11 & 7.5 & 25.0 & 10.0 & 0.5 & 7.69 & $2.89 \pm 2.51$ \\
12 & 7.5 & 30.0 & 15.0 & 0.5 & 30.51 & $9.71 \pm 1.02$ \\
\hline
\end{tabular}

A: pH; B: Salinity (ppt); C: Temperature $\left({ }^{\circ} \mathrm{C}\right) ; \mathrm{D}: \mathrm{NH}_{3} \mathrm{NO}_{4}$ concentration (g/L); E: Initial diesel concentration $(\mathrm{mg} / \mathrm{mL})$.

Table 5. ANOVA of the PBD model used to identify the factors significantly influencing diesel biodegradation.

\begin{tabular}{|c|c|c|c|c|c|}
\hline Source & Sum of Squares & DF & Mean Square & F Value & $p$ Value \\
\hline Model & 629.47 & 5 & 125.89 & 164.52 & $<0.0001^{* * *}$ \\
\hline $\mathrm{A}$ & 0.5663 & 1 & 0.56 & 0.74 & 0.4227 \\
\hline $\mathrm{B}$ & 4.62 & 1 & 4.62 & 6.04 & $0.0493 *$ \\
\hline $\mathrm{C}$ & 32.12 & 1 & 32.12 & 41.99 & $0.0006^{* * *}$ \\
\hline $\mathrm{D}$ & 376.17 & 1 & 376.17 & 491.59 & $<0.0001^{* * *}$ \\
\hline E & 215.98 & 1 & 215.98 & 282.24 & $<0.0001^{* * *}$ \\
\hline Residual & 4.59 & 6 & 0.7652 & & \\
\hline Cor Total & 634.06 & 11 & & & \\
\hline Std. Dev. & 0.87 .48 & \multicolumn{2}{|c|}{$\mathrm{R}^{2}$} & 0.9928 & \\
\hline Mean & 27.92 & \multicolumn{2}{|c|}{ Adjusted $\mathrm{R}^{2}$} & 0.9867 & \\
\hline C.V. & 3.13 & \multicolumn{2}{|c|}{ Predicted $\mathrm{R}^{2}$} & 0.9710 & \\
\hline & & \multicolumn{2}{|c|}{ Adequate Precision } & 36.4091 & \\
\hline
\end{tabular}

A: $\mathrm{pH}$; B: Salinity (ppt); C: Temperature $\left({ }^{\circ} \mathrm{C}\right) ; \mathrm{D}: \mathrm{NH}_{3} \mathrm{NO}_{4}$ concentration (g/L); E: Initial diesel concentration (mg $\left./ \mathrm{mL}\right) ;{ }^{*} p<0.05,{ }^{* *} p<0.01$, $* * * p<0.001$

\subsubsection{Central Composite Design}

After identification of the significant parameters in PBD, CCD was implemented to further optimise diesel biodegradation through identification and inclusion of significant pairwise interactions between these parameters. The incubation period used in CCD was $6 \mathrm{~d}$. The results of 30 experimental runs generated by CCD are given in Table 6, with the levels of diesel biodegradation ranging between $17.33 \%$ and $48.56 \%$. Run 10 in the model generated a negative value for parameter $\mathrm{E}$ (diesel concentration) and was not included in the analysis.

A quadratic model was chosen and ANOVA was used to assess the significance of each model term (Table 7).

To determine the optimal levels of each parameter for maximum diesel oil biodegradation, three-dimensional response surface plots were constructed by plotting the response (diesel degradation, $\mathrm{mg} / \mathrm{mL}$ ) on the $\mathrm{z}$-axis against any two independent parameters, while maintaining other parameters at their optimal values. These surface plots allowed for visualisation of the optimum values of each parameter that yielded the highest response. Figure $6 \mathrm{a}$ shows the interaction between salinity and nitrogen concentration. The combination of higher nitrogen concentration and lower salinity led to the greatest diesel degradation, reaching a maximum of $8.1 \mathrm{mg} / \mathrm{mL}$ with $1.5 \mathrm{~g} / \mathrm{L} \mathrm{NH}_{4} \mathrm{NO}_{3}$ and $25 \mathrm{ppt}$ 
$\mathrm{NaCl}$ with temperature and diesel concentration held at $10{ }^{\circ} \mathrm{C}$ and $4.0 \%(v / v)$, respectively. Figure $6 \mathrm{~b}$ illustrates the interaction between $\mathrm{NH}_{4} \mathrm{NO}_{3}$ concentration and temperature at a constant temperature. Diesel degradation was greatest between temperatures of $11^{\circ} \mathrm{C}$ and $13{ }^{\circ} \mathrm{C}$ at the highest $\mathrm{NH}_{4} \mathrm{NO}_{3}$ concentration of $1.5 \mathrm{~g} / \mathrm{L}$ with $8.1 \mathrm{mg} / \mathrm{mL}$ mass reduction from $18.54 \mathrm{mg} / \mathrm{mL}$ initial diesel concentration. Lower degradation values were predicted for higher temperatures, suggesting the inactivation of hydrocarbon-degrading enzymes and key metabolic players. Figure $6 \mathrm{c}$ shows the interaction between temperature and initial diesel concentration. Higher diesel reduction of $11.2 \mathrm{mg} / \mathrm{mL}$ was observed at lower temperatures of $10-12{ }^{\circ} \mathrm{C}$.

Table 6. Optimisation of parameters for diesel degradation by bacterial consortium $\mathrm{o} 2 \mathrm{~b}$ using central composite design (CCD) $( \pm \mathrm{SEM}, n=3)$.

\begin{tabular}{|c|c|c|c|c|c|c|}
\hline \multirow[t]{2}{*}{ Run Order } & \multirow[t]{2}{*}{ A } & \multirow[t]{2}{*}{ B } & \multirow[t]{2}{*}{$\mathrm{C}$} & \multirow[t]{2}{*}{ D } & \multicolumn{2}{|c|}{ Diesel Reduction (mg/mL) } \\
\hline & & & & & Experimental Value & Predicted Value \\
\hline 1 & 27.5 & 12.5 & 1.0 & 44.37 & $15.01 \pm 3.54$ & 14.84 \\
\hline 2 & 25.0 & 15.0 & 0.5 & 7.96 & $3.15 \pm 8.67$ & 2.71 \\
\hline 3 & 30.0 & 10.0 & 0.5 & 7.96 & $2.61 \pm 3.10$ & 2.27 \\
\hline 4 & 25.0 & 15.0 & 1.5 & 30.51 & $8.31 \pm 4.10$ & 8.78 \\
\hline 5 & 27.5 & 12.5 & 1.0 & 18.45 & $7.74 \pm 17.04$ & 7.63 \\
\hline 6 & 27.5 & 17.5 & 1.0 & 18.45 & $1.63 \pm 1.52$ & 1.41 \\
\hline 7 & 25.0 & 10.0 & 1.5 & 30.51 & $12.39 \pm 2.37$ & 11.67 \\
\hline 8 & 25.0 & 15.0 & 0.5 & 30.51 & $7.66 \pm 1.77$ & 7.91 \\
\hline 9 & 30.0 & 10.0 & 0.5 & 30.51 & $9.49 \pm 5.67$ & 9.67 \\
\hline 10 & 27.5 & 12.5 & 1.0 & 0 & 0.00 & 0.00 \\
\hline 11 & 32.5 & 12.5 & 1.0 & 18.45 & $5.83 \pm 0.21$ & 5.57 \\
\hline 12 & 30.0 & 15.0 & 0.5 & 7.96 & $1.89 \pm 1.28$ & 2.63 \\
\hline 13 & 30.0 & 10.0 & 1.5 & 7.96 & $2.88 \pm 1.57$ & 2.64 \\
\hline 14 & 27.5 & 12.5 & 0.0 & 18.45 & $6.43 \pm 9.94$ & 6.59 \\
\hline 15 & 27.5 & 12.5 & 1.0 & 18.45 & $7.88 \pm 0.96$ & 7.63 \\
\hline 16 & 25.0 & 10.0 & 1.5 & 7.96 & $3.87 \pm 4.40$ & 4.51 \\
\hline 17 & 25.0 & 15.0 & 1.5 & 7.96 & $3.11 \pm 2.14$ & 2.95 \\
\hline 18 & 30.0 & 15.0 & 0.5 & 30.51 & $9.2 \pm 2.06$ & 8.72 \\
\hline 19 & 27.5 & 12.5 & 1.0 & 18.45 & $7.72 \pm 0.43$ & 7.63 \\
\hline 20 & 25.0 & 10.0 & 0.5 & 30.51 & $9.16 \pm 9.50$ & 9.23 \\
\hline 21 & 30.0 & 15.0 & 1.5 & 30.51 & $8.08 \pm 3.67$ & 8.21 \\
\hline 22 & 27.5 & 12.5 & 1.0 & 18.45 & $7.85 \pm 0.04$ & 7.63 \\
\hline 23 & 27.5 & 12.5 & 1.0 & 18.45 & $7.09 \pm 0.99$ & 7.63 \\
\hline 24 & 30.0 & 10.0 & 1.5 & 30.51 & $10.09 \pm 3.33$ & 10.69 \\
\hline 25 & 27.5 & 12.5 & 2.0 & 18.45 & $8.18 \pm 2.75$ & 7.86 \\
\hline 26 & 27.5 & 7.5 & 1.0 & 18.45 & $3.86 \pm 1.02$ & 3.91 \\
\hline 27 & 27.5 & 12.5 & 1.0 & 18.45 & $7.48 \pm 13.19$ & 7.63 \\
\hline 28 & 30.0 & 15.0 & 1.5 & 7.96 & $1.37 \pm 17.36$ & 1.46 \\
\hline 29 & 22.5 & 12.5 & 1.0 & 18.45 & $6.54 \pm 2.76$ & 6.62 \\
\hline 30 & 25.0 & 10.0 & 0.5 & 7.96 & $2.84 \pm 6.79$ & 2.73 \\
\hline
\end{tabular}

A: Salinity (ppt); B: Temperature $\left({ }^{\circ} \mathrm{C}\right) ; \mathrm{C}: \mathrm{NH}_{3} \mathrm{NO}_{4}$ concentration (g/L); D: Initial diesel concentration (mg/mL). 
Table 7. Results of ANOVA for CCD model identifying factors and pairwise interactions significantly influencing diesel biodegradation.

\begin{tabular}{|c|c|c|c|c|c|c|}
\hline Source & Sum of & Df & Mean & F-Value & $p$ Value & \\
\hline Model & 307.675 & 14 & 21.977 & 85.488 & $<0.0001$ & $* * *$ \\
\hline A & 1.649 & 1 & 1.649 & 6.415 & 0.0239 & $*$ \\
\hline $\mathrm{B}$ & 9.397 & 1 & 9.397 & 36.553 & $<0.0001$ & $* * *$ \\
\hline $\mathrm{C}$ & 2.411 & 1 & 2.411 & 9.377 & 0.0084 & $* *$ \\
\hline $\mathrm{D}$ & 188.075 & 1 & 188.075 & 731.598 & $<0.0001$ & $* * *$ \\
\hline $\mathrm{AB}$ & 0.142 & 1 & 0.142 & 0.552 & 0.469 & \\
\hline $\mathrm{AC}$ & 1.987 & 1 & 1.987 & 7.728 & 0.014 & * \\
\hline AD & 0.791 & 1 & 0.791 & 3.078 & 0.101 & \\
\hline $\mathrm{BC}$ & 2.369 & 1 & 2.369 & 9.213 & 0.009 & $* *$ \\
\hline $\mathrm{BD}$ & 1.707 & 1 & 1.707 & 6.642 & 0.022 & $* *$ \\
\hline $\mathrm{CD}$ & 0.432 & 1 & 0.432 & 1.681 & 0.216 & \\
\hline $\mathrm{A}^{2}$ & 3.907 & 1 & 3.907 & 15.197 & 0.002 & $* *$ \\
\hline $\mathrm{B}^{2}$ & 41.091 & 1 & 41.091 & 159.839 & $<0.0001$ & $* * *$ \\
\hline$C^{2}$ & 0.273 & 1 & 0.273 & 1.060 & 0.321 & \\
\hline $\mathrm{D}^{2}$ & 0.347 & 1 & 0.347 & 1.351 & 0.265 & \\
\hline Residual & 3.599 & 14 & 0.257 & \multirow{3}{*}{3.883} & \multirow{3}{*}{0.075} & \\
\hline Lack of Fit & 3.149 & 9 & 0.350 & & & Not \\
\hline Pure Error & 0.450 & 5 & 0.090 & & & significant \\
\hline \multirow[t]{2}{*}{ Cor Total } & 311.274 & 28 & & & & \\
\hline & & & \multicolumn{2}{|l|}{$\mathrm{R}^{2}$} & 0.9894 & \\
\hline Std. Dev. & 0.507 & & \multicolumn{2}{|c|}{ Adjusted $\mathrm{R}^{2}$} & 0.9769 & \\
\hline Mean & 6.53 & & \multicolumn{2}{|c|}{ Predicted $\mathrm{R}^{2}$} & 0.9326 & \\
\hline C.V. $\%$ & 7.76 & & \multicolumn{2}{|c|}{ Adeq Precision } & 38.8315 & \\
\hline
\end{tabular}

A: Salinity, B: Temperature, $\mathrm{C}: \mathrm{NH}_{3} \mathrm{NO}_{4}$ concentration, D: Initial diesel concentration, ${ }^{*} p<0.05,{ }^{* *} p<0.01$ $* * * p<0.001$.

The model was validated by performing an experimental trial using the predicted optimised conditions displayed in Table 8 ( $\mathrm{pH} 8.0,25.0 \mathrm{ppt}, 1.5 \mathrm{~g} / \mathrm{L} \mathrm{NH}_{3} \mathrm{NO}_{4}, 10^{\circ} \mathrm{C}$ and $4.0 \%$ $(v / v)$ diesel). The program predicted a value of $11.66 \mathrm{mg} / \mathrm{mL}$ for total diesel mass reduction. These conditions applied experimentally yielded a not significantly different degradation of $12.23 \mathrm{mg} / \mathrm{mL} \pm 1.46$ from the initial $30.518 \mathrm{mg} / \mathrm{mL}$ (two-tailed $\mathrm{t}$ test, $p=0.506$ ).

Table 8. Model validation using the predicted optima values.

\begin{tabular}{cccc}
\hline Optimised Parameters & Value & Predicted Value & Experimental Value \\
\hline $\mathrm{pH}$ & 8.0 & & \\
Salinity $(\mathrm{NaCl})$ & $25.0 \mathrm{ppt}$ & & \\
Temperature & $10{ }^{\circ} \mathrm{C}$ & $11.66 \mathrm{mg} / \mathrm{mL}$ & $12.23 \mathrm{mg} / \mathrm{mL} \pm 1.46$ \\
$\mathrm{NH}_{3} \mathrm{NO}_{4}$ concentration & $1.5 \mathrm{~g} / \mathrm{L}$ & & \\
Initial diesel concentration & $4.0 \%$ & & \\
\hline
\end{tabular}



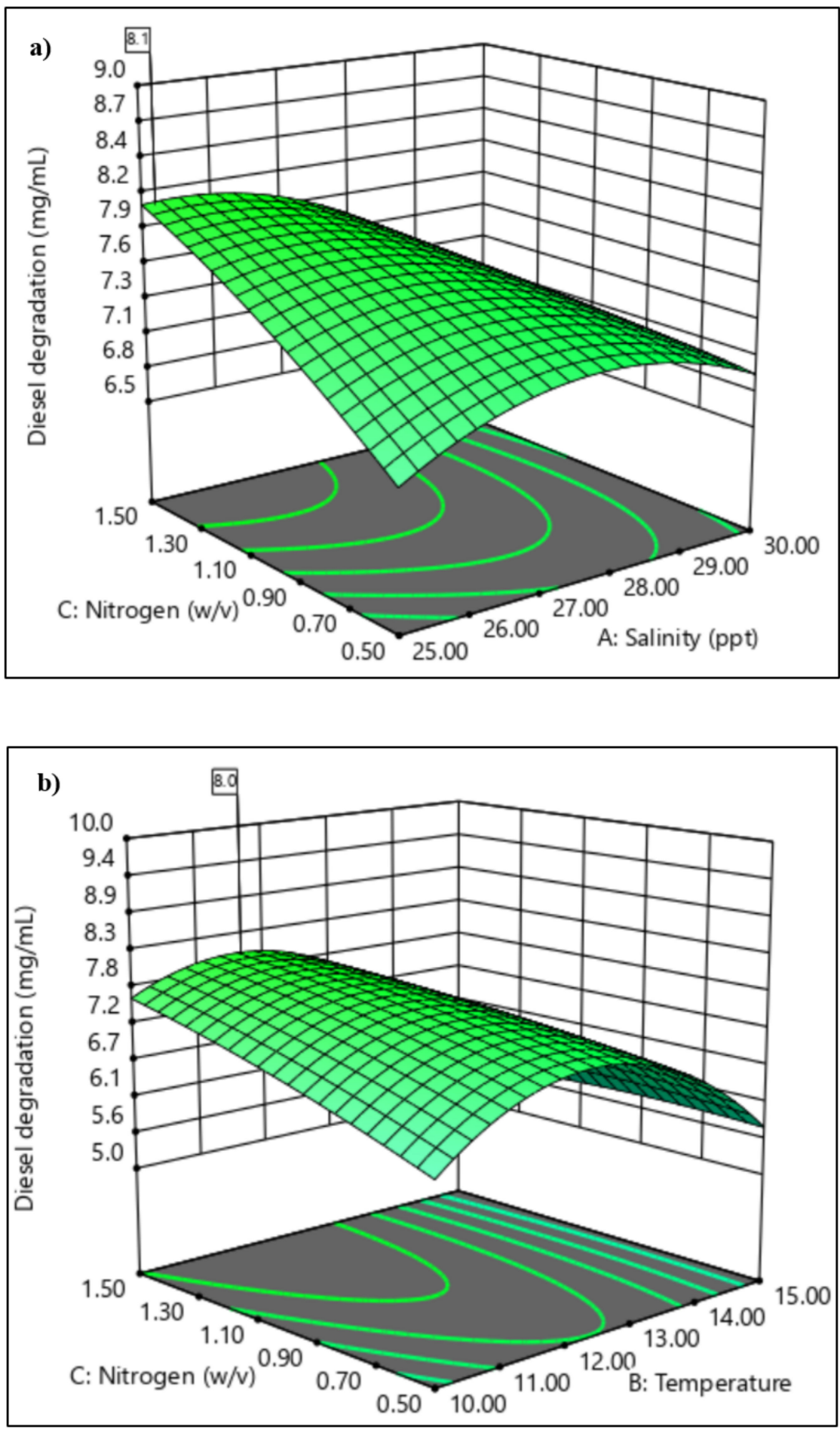

Figure 6. Cont. 


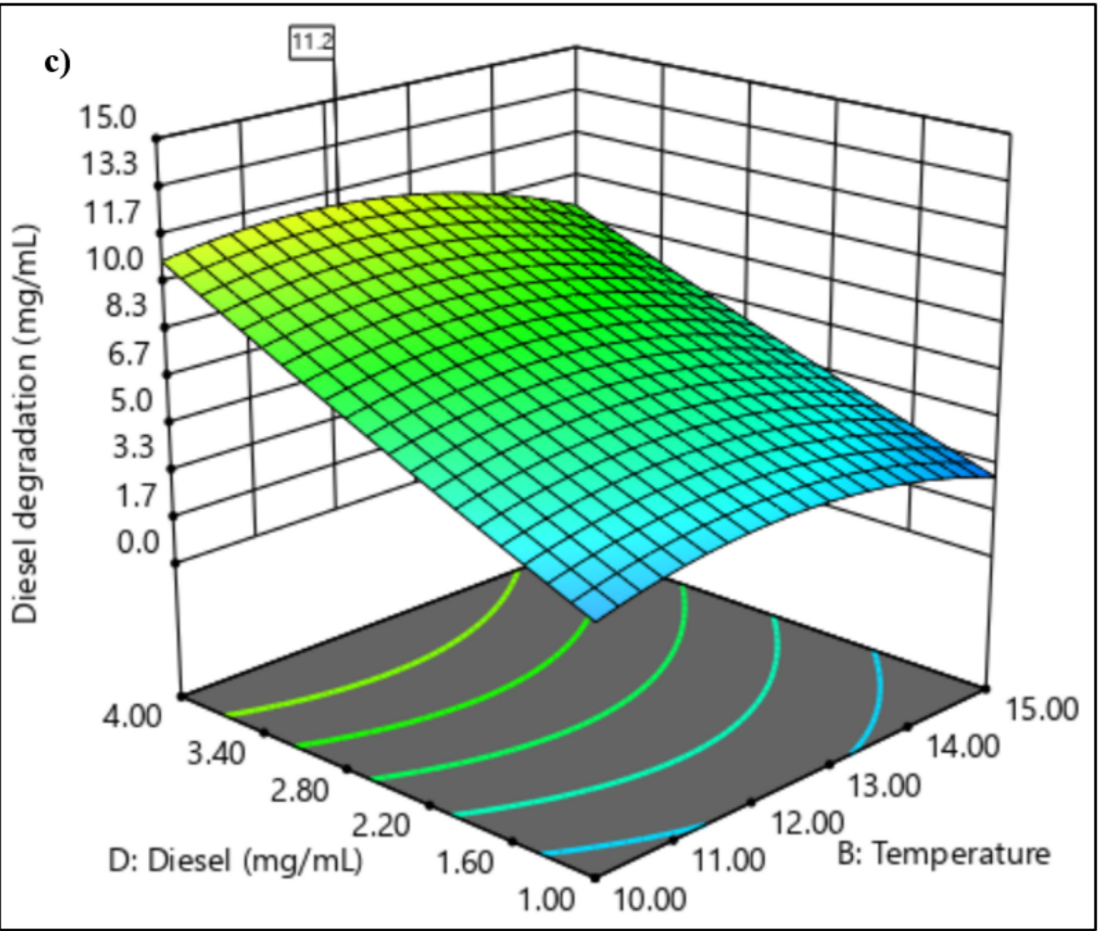

Figure 6. 3D Contour plots generated by Design Expert (Stat Ease, Inc) of the significantly interacting model terms (a) A: salinity and C: $\mathrm{NH}_{3} \mathrm{NO}_{4}$ concentration, (b) B: temperature and $\mathrm{C}: \mathrm{NH}_{3} \mathrm{NO}_{4}$ concentration, (c) B: temperature and D: diesel concentration.

\section{Discussion}

Natural microbial communities can be distinguished into three general groups: saprophytic, symbiotic and parasitic [51]. Hydrocarbon-degrading microorganisms constitute between 1 and $10 \%$ of the total number of saprophytic microorganisms in marine microbial communities [52,53], and heterotrophic bacteria near the ocean's surface decompose $75-95 \%$ of the organic matter generated by autotrophic organisms in the photic zone [54]. On this basis, microbial mineralisation of diesel hydrocarbon molecules is primarily expected to occur near the ocean's surface [55]. The current study relied on bacterial consortium samples obtained from a shallow marine environment with no history or evidence of hydrocarbon contamination. However, even in uncontaminated areas such as these, bacteria capable of hydrocarbon-degradation are still expected to be ubiquitous [22,56]. In the event of hydrocarbon contamination of the natural environment, the autochthonous microbiota initially present are subjected to strong selection pressure, with only those with appropriate resistance characteristics essential for survival and capable of expressing specific enzymatic biodegrading pathways ultimately remaining [57].

\subsection{Optimisation of Growth Conditions Using Conventional One-Factor-at-a-Time}

\subsection{1. $\mathrm{pH}$}

The $\mathrm{pH}$ value of the surrounding environment plays a crucial role in microbial mineralisation of diesel as a sole carbon source. Surface ocean water worldwide, including in the Antarctic, is alkaline, typically ranging from $\mathrm{pH} 7.9$ to 8.2 [58,59]. Generally, the buffering capacity of seawater reaches a minimum at a $\mathrm{pH}$ value of approximately 7.5 [60,61], consistent with the non-significant difference in diesel degradation observed here between $\mathrm{pH} 7.5$ and 8.0 in the phosphate buffer system. The $\mathrm{pH}$ of the growth medium influences microbial growth and metabolism, enzymatic activities, transport processes and nutrient solubility [62]. Many heterotrophic bacteria, and in particular soil-dwelling species, perform optimally at a pH close to neutral (e.g., [42]). However, marine bacteria can survive and grow in a slightly alkaline environment $[63,64]$. Marine microbes can also adapt to changes in environmental $\mathrm{pH}$ [55], although maintain a cytoplasmic $\mathrm{pH}$ between 7.4 and 
7.8 [65] that is compatible with optimal function and structural integrity of the cytoplasmic proteins that support growth [66]. The presence of phosphorus-containing compounds in the experimental buffer system used may itself have made a nutritional contribution to the microbial cells encouraging bacterial growth [67]. In the oceanic environment, the natural concentration of $P$ is non-limiting for microbial uptake. However, under oil spill conditions, the concentration of $\mathrm{P}$ is altered and it can become a limiting factor [68].

\subsubsection{Salinity}

The data obtained here are comparable to those of Yakimov et al. [69], who reported optimal bacterial growth between $30-40$ ppt salinity. The ocean surrounding the northwestern Antarctic Peninsula, where General Bernardo O'Higgins station is located, forms part of the Southern Ocean, which surrounds the entire Antarctic continent and is bounded by the Antarctic Circumpolar, which provides some isolation from the waters of other oceans. The Southern Ocean has a typical salinity range of 33.0 to 34.6 [59]. A study carried out in the western Antarctic Peninsula region, close to the current study's sampling location, reported a salinity range of 32.5-35.5 ppt in a dataset collected over 19 years [70].

\subsubsection{Temperature}

The western Antarctic Peninsula (WAP) was one of the most rapidly warming regions on the planet in the second half of the twentieth century, with a surface air temperature warming rate of $3.7 \pm 1.6^{\circ} \mathrm{C}$ per century [71-73]. Surface waters of the Southern Ocean close to the continent have also warmed [74,75], with some evidence also of warming of the Circumpolar Deep Water that surrounds the Antarctic continent [76]. RodriguesBlanco et al. [77] suggested that, although temperature and substrate are crucial to bacterial growth, different bacterial species respond differently to temperature. The majority of microbial strains isolated in Antarctic seawater are considered psychrotolerant, rather than true psyhchrophiles [53]. The bacterial consortium o2b studied here is likely to contain a mixture of psychrotolerant and psychrophilic bacteria. Low bacterial growth, such as seen at the higher temperatures used here, can be associated with the denaturation of key cellular components, while low temperatures may restrict bacterial growth through the loss of membrane function [78]. Within the functional temperature range of a given species, microbial metabolism increases with temperature [79], while diesel uptake or assimilation is also affected by temperature [80]. In the presence of diesel, temperature can influence the active bacterial community structure because only some species are responsible for the biodegradation of specific hydrocarbons [81,82]. Alkanes are the first hydrocarbons to be utilised [83], as they are more bioavailable. The resulting proportional increase in aromatic hydrocarbons remaining will generate a dynamic shift within the bacterial consortium, with an increase in the fraction of bacteria that can utilise these more complex compounds [84,85].

\subsubsection{Nitrogen: Source and Concentration}

The enhancement in the degradation achieved in the presence of $\mathrm{NH}_{3} \mathrm{NO}_{4}$ (Figure 4a) may be explained by the fact that hydrocarbons exist in a reduced state, and they are oxidised by microbes using electron acceptors. Since oxygen can also become a limiting factor, electron acceptors added to substitute for oxygen may indicate that the nitrate ion provided the next best alternative [86]. Nitrate gives high oxidation potential for the removal of hydrocarbon contamination [87]. Moreover, the additional $\mathrm{N}$ can act as a macronutrient supporting the synthesis of amino acids and nucleic acids and allowing rapid cell growth in the medium [88]. Diesel reduction was considerably higher in $\mathrm{NH}_{3} \mathrm{NO}_{4}$, urea, $\mathrm{NH}_{4} \mathrm{Cl}$ and $\mathrm{NH}_{4} \mathrm{SO}_{4}$. However, the choice of the nitrogen source is also influenced by cost and environmental impacts. Urea is considered to be an expensive source of nitrogen in comparison to $\mathrm{NH}_{3} \mathrm{NO}_{4}$ [89]. $\mathrm{NH}_{3} \mathrm{NO}_{4}$ is predominantly used and manufactured for applications in agriculture, mining, quarrying and civil construction [90]. 
At higher concentrations of ammonium nitrate, diesel degradation began to reduce, suggesting more studies are required to properly ascertain the amount of nitrogen needed to sustain the key microbial players needed for diesel degradation. It is important not to indiscriminately add nitrogen because of the potentially harmful impact its overfertilisation will have on the environment. Microbial communities utilise fuel as a source of carbon and increase the demand for inorganic nutrients like nitrogen [91]. As a result, increased nutrient demand makes nitrogen bioavailability a limiting factor that controls hydrocarbon biodegradation in marine oil-impacted environments [92]. The use of nitrogen has also been reported to be optimum at salinity levels of 20-25 ppt, whereas lower nitrogen turnover occurred at salinity $30 \mathrm{ppt}$ [93]. It has been established that $\mathrm{N}$ can improve the biodegradation of hydrocarbons of marine microorganisms. Even though inorganic N, such as $\mathrm{NO}_{3}{ }^{-}$and $\mathrm{NH}_{4}{ }^{+}$, limits the extent of hydrocarbon degradation in the marine environment, optimum concentrations can benefit the process of bioremediation of oilcontaminated marine environments [94].

\subsubsection{Diesel Concentration}

Some microbial species are known to tolerate high concentrations of diesel [42,95]. The initial substrate concentration affects the uptake and degradation of the hydrocarbon compound [96]. As noted above, when exposed to a mixture of hydrocarbons, as would be the case in a diesel spill, initially the more readily biodegradable components will be degraded, leading to rapid growth and high levels of respiration [97]. Alkanes of intermediate chain length are typically degraded rapidly, whereas longer chain alkanes and the more toxic aromatic compounds are more recalcitrant and persist for a longer period of time [53]. In the current study there was a considerable reduction in diesel biodegradation at the highest initial diesel concentration trialled (5.5\% v/v; Figure 5), suggesting that the key biodegrading members of consortium $\mathrm{o} 2 \mathrm{~b}$ could not tolerate that high of a concentration.

\subsection{Application of Response Surface Methodology in the Selection of Significant Variables}

Screening using PBD evaluates the influence of each of the selected environmental parameters separately on the degradation process [98]. In this study, all of the independent environmental factors were significant. The subsequent use of CCD allowed identification of the significant pairwise interactions between them (Figure 6). The optimisation results obtained through RSM revealed that the data fitted well with the quadratic model (Table 7). CCD predicted higher diesel biodegradation at lower salinity and higher nitrogen concentration. However, the response surfaces generated also support the adaptability or flexibility of the hydrocarbon-degrading members of bacterial consortium $\mathrm{o} 2 \mathrm{~b}$, which can tolerate varying salinity levels while still maintaining considerable, if sub-optimal, biodegradation ability.

Temperature was a key factor influencing biodegradation of hydrocarbons by bacterial consortium o $2 \mathrm{~b}$. In general, chemical reactions obey the Arrhenius relationship, where rates increase with temperature, modulated in biological enzyme-mediated reactions by the properties of the enzymes involved. The data obtained here clearly show that consortium $\mathrm{o} 2 \mathrm{~b}$ achieved maximum hydrocarbon degradation at the relatively low temperature of $10-12{ }^{\circ} \mathrm{C}$ (Figure $6 \mathrm{c}$ ). A further effect of temperature on the rate of hydrocarbon degradation acts through its influence on $\mathrm{N}$ availability (Figure $6 \mathrm{~b}$ ). This is consistent with a study in the sub-Antarctic Kerguelen archipelago, where temperatures of $10{ }^{\circ} \mathrm{C}$ and $20{ }^{\circ} \mathrm{C}$, in the presence of diesel fuel and varying nitrogen concentrations, induced changes in the total bacterial consortium in seawater, while at $4{ }^{\circ} \mathrm{C}$ the consortium structure remained stable [77]. Temperature also affects the availability of the oil due to the physical nature of the hydrocarbons.

Community interactions in natural consortia are of paramount importance when considering the biodegradation of complex hydrocarbon mixtures, such as crude oil and diesel. A natural consortium can degrade a complex mixture of hydrocarbons more effectively because of complementary interdependence between its members [99]. Such interactions 
may be crucial for the preliminary steps that eventually lead to the mineralisation of the hydrocarbon compounds. Most research to date has focused on hydrocarbon degrading marine microbial taxa, ignoring any nitrifying species present. Nitrifiers, which comprise both bacteria and archaea, are more sensitive to hydrocarbon toxicity than are typical heterotrophs. Thus, when an oil spill occurs in coastal ecosystems, a loss of nitrification activity follows. Denitrification is then driven by heterotrophs, slowing down nitrogen turnover and as a consequence, increasing ammonia availability, which supports the growth of oil-degrading heterotrophs. Nitrifying bacteria naturally present in the environment are also expected to play a role in remediating oil [100]. For ammonium-oxidising bacteria, exposure to hydrocarbons causes disruption to the outer membrane of the cell, along with the formation of toxic products from hydrocarbon metabolism that are cytotoxic [101].

\section{Conclusions}

This study examined the ability of marine bacterial consortia from uncontaminated Antarctic seawater to biodegrade diesel. The optimisation of the consortium o $2 \mathrm{~b}$ through the application of both conventional OFAT and the statistical approach of RSM, yielded a reduction of $12.23 \mathrm{mg} / \mathrm{mL}$ from the initial $30.518 \mathrm{mg} / \mathrm{mL}$ concentration of diesel $(4 \%$ $v / v$ ). The optimisation of diesel biodegradation also provided a better understanding of how different parameters influenced one another in response to diesel biodegradation by an Antarctic bacterial consortium, confirming that salinity, nitrogen concentration, initial diesel concentration and temperature all significantly influenced diesel degradation. Further significant pairwise interactions were found between salinity and nitrogen, nitrogen and temperature and diesel concentration and temperature. Consortium studies provide a realistic assessment of how natural microbial communities are affected by hydrocarbon pollution and of how changing environmental conditions could impinge on different consortia.

Author Contributions: Conceptualization, S.A.A., C.G.-F. and A.Z.; methodology, S.A.A., N.N.Z. and K.A.K.; software, N.N.Z., K.A.K. and A.F.A.R.; validation, S.A.A., K.A.K., P.C. and C.G.-F.; formal analysis, N.N.Z., S.A.A. and K.A.K.; investigation, N.N.Z.; resources, S.A.A., C.G.-F. and L.C.; original draft preparation, N.N.Z.; Writing-review and editing S.A.A., C.G.-F., K.A.K., P.C., A.F.A.R., A.Z., S.S., N.A.S. and L.C.; supervision, S.A.A., C.G.-F., K.A.K., P.C., A.Z., S.S. and N.A.S.; project administration, S.A.A. and C.G.-F.; funding acquisition, S.A.A. and C.G.-F. All authors have read and agreed to the published version of the manuscript.

Funding: This project was financially supported by Putra-IPM fund under the research grant attached to S.A. Ahmad (GPM-2018/9660000, GPM-2019/9678900, 2017/ 9300436) disbursed by Universiti Putra Malaysia (UPM) and YPASM Smart Partnership Initiative (6300247) by Sultan Mizan Antarctic Research Foundation (YPASM). P. Convey is supported by NERC core funding to the British Antarctic Survey's 'Biodiversity. Evolution and Adaptation' Team. C.G. Fuentes is supported by Centro de Investigacion y Monitoreo Ambiental Antàrctico (CIMAA) Project. A. F. A. Roslee is funded by a Public Service Department of Malaysia (JPA) scholarship. L. Cárdenas is funded by the Fondap Center IDEAL 1500003.

Institutional Review Board Statement: Not applicable.

Informed Consent Statement: Not applicable.

Data Availability Statement: Not applicable.

Acknowledgments: The authors thank Universiti Putra Malaysia, Universidad de Magallanes, Centro de Investigacion y Monitoreo Ambiental Antàrctico (CIMAA), Sultan Mizan Antarctic Research Foundation (YPASM), Chilean Army and the Antarctic General Bernardo O'Higgins Station staff especially the Comandante de la Base O'Higgins; Teniente Coronel Jose Ignacio Alvarado Camps, the Comandante de la sección de exploracion y rescate O’higgins; Capitan René Salgado Rebolledo and the staff, Instituto Antártico Chileno (INACH) and the Malaysian National Antarctic Research Centre (NARC).

Conflicts of Interest: The authors declare no conflict of interest. 


\section{References}

1. Martins, C.C.; Bicego, M.C.; Taniguchi, S.; Montone, R.C. Aliphatic and polycyclic aromatic hydrocarbons in surface sediments in Admiralty Bay, King George Island, Antarctica. Antarct. Sci. 2004, 16, 117-122. [CrossRef]

2. Cripps, G.C.; Shears, J. The fate in the marine environment of a minor diesel fuel spill from an Antarctic research station. Environ. Monit. Assess. 1997, 46, 221-232. [CrossRef]

3. Stewart, E.J.; Draper, D. The sinking of the MS explorer: Implications for cruise tourism in Arctic Canada. Arctic 2008, 61, 224. [CrossRef]

4. Stark, J.S.; Mohammad, M.; McMinn, A.; Ingels, J. The effects of hydrocarbons on meiofauna in marine sediments in Antarctica. J. Exp. Mar. Biol. Ecol. 2017, 496, 56-73. [CrossRef]

5. Khalid, F.E.; Lim, Z.S.; Sabri, S.; Gomez-Fuentes, C.; Zulkharnain, A.; Ahmad, S.A. Bioremediation of diesel contaminated marine water by bacteria: A review and bibliometric analysis. J. Mar. Sci. Eng. 2021, 9, 155. [CrossRef]

6. Hull, B.; Bergstrom, D. Antarctic terrestrial and limnetic ecosystem conservation and management. In Trends in Antarctic Terrestrial and Limnetic Ecosystems; Bergstrom, D.M., Convey, P., Huiskes, A.H.L., Eds.; Springer: Cham, Switzerland, 2006; pp. 317-340. [CrossRef]

7. Kennicutt, M.C.; Sweet, S.T.; Fraser, W.R.; Stockton, W.L.; Culver, M. The Fate of Diesel Fuel Spilled by the Bahia Paraiso in Arthur Harbor, Antarctica. In Proceedings of the 1991 International Oil Spill Conference, San Diego, California, USA, 4-7 March 1991; pp. 493-500. [CrossRef]

8. Wilkness, P. Fuel spill clean up in the Antarctic. Antarct. J. USA 1990, 25, 3-8.

9. Hamanaka, R.; Obara, S. Study on the Fuel Consumption in the Antarctica Showa Base Microgrid. In Proceedings of the IEEE PES Asia-Pacific Power and Energy Engineering Conference (APPEEC), Xian, China, 25-28 October 2016. [CrossRef]

10. Brooks, S.T.; Jabour, J.; Sharman, A.J.; Bergstrom, D.M. An analysis of environmental incidents for a national Antarctic program. J. Environ. Manag. 2018, 212, 340-348. [CrossRef] [PubMed]

11. Dou, Y.; Zuo, G.; Chang, X.; Chen, Y. A study of a standalone renewable energy system of the Chinese Zhongshan Station in Antarctica. Appl. Sci. 2019, 9, 1968. [CrossRef]

12. Aislabie, J.M.; Balks, M.R.; Astori, N.; Stevenson, G.; Symons, R. Polycyclic aromatic hydrocarbons in fuel-oil contaminated soils, Antarctica. Chemosphere 1999, 39, 2201-2207. [CrossRef]

13. Bargagli, R. Environmental contamination in Antarctic ecosystems. Sci. Total Environ. 2008, 400, 212-226. [CrossRef] [PubMed]

14. Cabrerizo, A.; Tejedo, P.; Dachs, J.; Benayas, J. Anthropogenic and biogenic hydrocarbons in soils and vegetation from the South Shetland Islands (Antarctica). Sci. Total Environ. 2016, 569, 1500-1509. [CrossRef]

15. Wong, R.R.; Lim, Z.S.; Shaharuddin, N.A.; Zulkharnain, A.; Gomez-Fuentes, C.; Ahmad, S.A. Diesel in Antarctica and a bibliometric study on its indigenous microorganisms as remediation agent. Int. J. Environ. Res. Public Health 2021, 18, 1512. [CrossRef] [PubMed]

16. Zakaria, N.N.; Convey, P.; Gomez-Fuentes, C.; Zulkharnain, A.; Sabri, S.; Shaharuddin, N.A.; Ahmad, S.A. Oil bioremediation in the marine environment of Antarctica: A review and bibliometric keyword cluster analysis. Microorganisms 2021, 9, 419. [CrossRef]

17. Tin, T.; Fleming, Z.L.; Hughes, K.A.; Ainley, D.G.; Convey, P.; Moreno, C.A.; Pfeiffer, S.; Scott, J.; Snape, I. Impacts of local human activities on the Antarctic environment. Antarct. Sci. 2009, 21, 3-33. [CrossRef]

18. Fuoco, R.; Giannarelli, S.; Wei, Y.; Abete, C.; Francesconi, S.; Termine, M. Polychlorobiphenyls and polycyclic aromatic hydrocarbons in the sea-surface micro-layer and the water column at Gerlache Inlet, Antarctica. J. Environ. Monit. 2005, 7, 1313-1319. [CrossRef]

19. Stortini, A.M.; Martellini, T.; Del Bubba, M.; Lepri, L.; Capodaglio, G.; Cincinelli, A. n-Alkanes, PAHs and surfactants in the sea surface microlayer and sea water samples of the Gerlache Inlet Sea (Antarctica). Microchem. J. 2009, 92, 37-43. [CrossRef]

20. Gutierrez, T. Occurrence and roles of the obligate hydrocarbonoclastic bacteria in the ocean when there is no obvious hydrocarbon contamination. In Taxonomy, Genomics and Ecophysiology of Hydrocarbon-degrading Microbes (Handbook of Hydrocarbon and Lipid Microbiology); McGenity, T.J., Ed.; Springer: Cham, Switzerland, 2018; pp. 1-17. [CrossRef]

21. Yakimov, M.M.; Timmis, K.N.; Golyshin, P.N. Obligate oil-degrading marine bacteria. Curr. Opin. Biotechnol. 2007, 18, 257-266. [CrossRef]

22. Lo Giudice, A.; Casella, P.; Caruso, C.; Mangano, S.; Bruni, V.; De Domenico, M.; Michaud, L. Occurrence and characterization of psychrotolerant hydrocarbon-oxidizing bacteria from surface seawater along the Victoria Land coast (Antarctica). Polar Biol. 2010, 33, 929-943. [CrossRef]

23. Gentile, G.; Bonsignore, M.; Santisi, S.; Catalfamo, M.; Giuliano, L.; Genovese, L.; Yakimov, M.M.; Denaro, R.; Genovese, M.; Cappello, S. Biodegradation potentiality of psychrophilic bacterial strain Oleispira antarctica RB-8T. Mar. Pollut. Bull. 2016, 105, 125-130. [CrossRef]

24. Radwan, S.S.; Khanafer, M.M.; Al-Awadhi, H.A. Ability of the so-called obligate hydrocarbonoclastic bacteria to utilize nonhydrocarbon substrates thus enhancing their activities despite their misleading name. BMC Microbiol. 2019, 19, 41. [CrossRef] [PubMed]

25. Atlas, R.M.; Hazen, T.C. Oil biodegradation and bioremediation: A tale of the two worst spills in US history. Environ. Sci. Technol. 2011, 45, 6709-6715. [CrossRef] [PubMed] 
26. Rodríguez, C.; Iglesias, K.; Bicego, M.; Taniguchi, S.; Sasaki, S.T.; Kandratavicius, N.; Bueno, C.; Brugnoli, E.; Venturini, N. Hydrocarbons in soil and meltwater stream sediments near Artigas Antarctic Research Station: Origin, sources and levels. Antarct. Sci. 2018, 30, 1-13. [CrossRef]

27. Brussaard, C.P.D.; Peperzak, L.; Beggah, S.; Wick, L.Y.; Wuerz, B.; Weber, J.; Arey, J.S.; van der Burg, B.; Jonas, A.; Huisman, J.; et al. Immediate ecotoxicological effects of short-lived oil spills on marine biota. Nat. Commun. 2016, 4, 11206. [CrossRef] [PubMed]

28. Mandri, T.; Lin, J. Isolation and characterization of engine oil degrading indigenous microorganisms in Kwazulu-Natal, South Africa. Afr. J. Biotechnol. 2007, 6, 23-27. [CrossRef]

29. Prince, R.C. Bioremediation of marine oil spills. In Handbook of Hydrocarbon and Lipid Microbiology; Timmis, K.N., Ed.; Springer: Berlin/Heidelberg, Germany, 2010; Chapter 16; pp. 2618-2626. [CrossRef]

30. Guerra, A.B.; Oliveira, J.S.; Silva-Portela, R.C.; Araujo, W.; Carlos, A.C.; Vasconcelos, A.T.R.; Freitas, A.T.; Domingos, Y.S.; de Farias, M.F.; Fernandes, G.J.T.; et al. Metagenome enrichment approach used for selection of oil-degrading bacteria consortia for drill cutting residue bioremediation. Environ. Pollut. 2018, 235, 869-880. [CrossRef]

31. Margesin, R.; Moertelmaier, C.; Mair, J. Low-temperature biodegradation of petroleum hydrocarbons (n-alkanes, phenol, anthracene, pyrene) by four actinobacterial strains. Int. Biodeterior. Biodegrad. 2013, 84, 185-191. [CrossRef]

32. Kim, S.J.; Kweon, O.; Sutherland, J.B.; Kim, H.L.; Jones, R.C.; Burback, B.L.; Graves, B.L.; Psurny, E.; Cerniglia, C.E. Dynamic response of Mycobacterium vanbaalenii PYR-1 to BP Deepwater Horizon crude oil. Appl. Environ. Microbiol. 2015, 81, 4263-4276. [CrossRef]

33. Cai, Q.H.; Zhang, B.Y.; Chen, B.; Zhu, Z.W.; Lin, W.Y.; Cao, T. Screening of biosurfactant producers from petroleum hydrocarbon contaminated sources in cold marine environments. Mar. Pollut. Bull. 2014, 86, 402-410. [CrossRef]

34. De Domenico, M.; Lo Giudice, A.; Michaud, L.; Saitta, M.; Bruni, V. Diesel oil and PCB-degrading psychrotrophic bacteria isolated from Antarctic seawaters (Terra Nova Bay, Ross Sea). Polar Res. 2004, 23, 141-146. [CrossRef]

35. Gurav, R.; Lyu, H.; Ma, J.; Tang, J.; Liu, Q.; Zhang, H. Degradation of n-alkanes and PAHs from the heavy crude oil using salt-tolerant bacterial consortia and analysis of their catabolic genes. Environ. Sci. Pollut. Res. 2017, 24, 11392-11403. [CrossRef]

36. Crisafi, F.; Giuliano, L.; Yakimov, M.M.; Azzaro, M.; Denaro, R. Isolation and degradation potential of a cold-adapted oil/PAHdegrading marine bacterial consortium from Kongsfjorden (Arctic region). Rend. Lincei 2016, 27 (Suppl. S1), 261-270. [CrossRef]

37. Powell, S.; Stark, J.; Snape, I.; Woolfenden, E.; Bowman, J.; Riddle, M. Effects of diesel and lubricant oils on Antarctic benthic microbial communities over five years. Aquat. Microb. Ecol. 2010, 59, 119-127. [CrossRef]

38. Rizzo, C.C.; Malavenda, R.; Gerçe, B.; Papale, M.; Syldatk, C.; Hausmann, R.; Bruni, V.; Michaud, L.; Lo Giudice, A.; Amalfitano, $\mathrm{S}$. Effects of a simulated acute oil spillage on bacterial communities from Arctic and Antarctic marine sediments. Microorganisms 2019, 7, 632. [CrossRef] [PubMed]

39. Brown, K.E.; King, C.K.; Harrison, P.L. Impacts of petroleum fuels on fertilization and development of the Antarctic sea urchin Sterechinus neumayeri. Environ. Toxicol. Chem. 2020, 39, 2527-2539. [CrossRef] [PubMed]

40. Dvořák, P.; Nikel, P.I.; Damborský, J.; de Lorenzo, V. Bioremediation 3.0: Engineering pollutant-removing bacteria in the times of systemic biology. Biotechnol. Adv. 2017, 35, 845-866. [CrossRef] [PubMed]

41. De Jesus, H.E.; Peixoto, R.S.; Rosado, A.S. Bioremediation in Antarctic Soils. J. Pet. Environ. Biotechnol. 2015, 6, 6. [CrossRef]

42. Roslee, A.; Zakaria, N.N.; Convey, P.; Zulkharnain, A.; Lee, G.; Gomez-Fuentes, C.; Ahmad, S.A. Statistical optimisation of growth conditions and diesel degradation by the Antarctic bacterium, Rhodococcus sp. strain AQ5-07. Extremophiles 2020, 24, 277-291. [CrossRef]

43. Yang, S.Z.; Wen, X.; Shi, Y.L.; Liebner, S.; Jin, H.J.; Perfumo, A. Hydrocarbon degraders establish at the costs of microbial richness, abundance and keystone taxa after crude oil contamination in permafrost environments. Sci. Rep. 2016, 6, 37473. [CrossRef] [PubMed]

44. Tengku-Mazuki, T.; Subramaniam, K.; Zakaria, N.; Convey, P.; Abdul Khalil, K.; Lee, G.; Zulkharnain, A.; Shaharuddin, N.A.; Ahmad, S. Optimization of phenol degradation by Antarctic bacterium Rhodococcus sp. Antarct. Sci. 2020, 32, 486-495. [CrossRef]

45. Bushnell, L.D.; Haas, H.F. The utilization of certain hydrocarbons by microorganisms. J. Bacteriol. 1941, 41, 653-673. [CrossRef]

46. Silva, E.J.; Correa, P.F.; Almeidaa, D.G.; Lunaa, J.M.; Rufino, R.D.; Sarubbo, L.A. Recovery of contaminated marine environments by biosurfactant-enhanced bioremediation. Colloids Surf. B Biointerfaces 2018, 172, 127-135. [CrossRef]

47. Chen, Q.; Bao, M.; Fan, X.; Liang, S.; Sun, P. Rhamnolipids enhance marine oil spill bioremediation in laboratory system. Mar. Pollut. Bull. 2013, 71, 269-275. [CrossRef] [PubMed]

48. McFarlin, K.M.; Perkins, M.J.; Field, J.A.; Leigh, M.B. Biodegradation of crude oil and corexit 9500 in Arctic seawater. Front. Microbiol. 2018, 9, 1788. [CrossRef]

49. Plackett, R.L.; Burman, J.P. The design of optimum multifactorial experiments. Biometals 1946, 33, 305-325. [CrossRef]

50. Xiao, Z.J.; Liu, P.H.; Qin, J.Y.; Xu, P. Statistical optimization of medium components for enhanced acetoin production from molasses and soybean meal hydrolyzate. Appl. Microbiol. Biotechnol. 2007, 74, 61-68. [CrossRef] [PubMed]

51. Coelho, L.C. Saprophytic, symbiotic and parasitic bacteria: Importance to environment, biotechnological applications and biocontrol. Adv. Res. 2014, 2, 250-265. [CrossRef]

52. Wright, A.L.; Weaver, R.W.; Webb, J.W. Oil bioremediation in salt marsh mesocosms as influences by $\mathrm{N}$ and $\mathrm{P}$ fertilisation, flooding and season. Water Air Soil Pollut. 1997, 95, 179-191. [CrossRef]

53. Delille, D.; Delille, B.; Pelletier, E. Effectiveness of bioremediation of crude oil contaminated subantarctic intertidal sediment: The microbial response. Microb. Ecol. 2002, 44, 118-126. [CrossRef] [PubMed] 
54. Boyd, P.W.; Sherry, N.D.; Berges, J.A.; Bishop, J.K.B.; Calvert, S.E.; Charette, M.A.; Giovannoni, S.J.; Goldblatt, R.; Harrison, P.J.; Moran, S.B.; et al. Transformations of biogenic particulates from the pelagic to the deep ocean realm. Deep Sea Res. Part II 1999, 46, 2761-2792. [CrossRef]

55. Das, S.; Mangwani, N. Ocean acidification and marine microorganisms: Responses and consequences. Oceanologia 2015, 57, 349-361. [CrossRef]

56. Atlas, R.M. Fate of petroleum pollutants in Arctic ecosystems. Water Sci. Technol. 1986, 18, 59-67. [CrossRef]

57. Pereira, E.; Napp, A.; Allebrandt, S.; Barbosa, R.; Reuwsaat, J.; Lopes, W.; Kmetzsch, L.; Staats, C.; Schrank, A.; Dallegrave, A.; et al. Biodegradation of aliphatic and polycyclic aromatic hydrocarbons in seawater by autochthonous microorganisms. Int. Biodeterior. Biodegrad. 2019, 145, 104789. [CrossRef]

58. Rivaro, P.; Messa, R.; Ianni, C.; Magi, E.; Budillon, G. Distribution of total alkalinity and pH in the Ross Sea (Antarctica) waters during austral summer 2008. Polar Res. 2014, 33, 20403. [CrossRef]

59. Takahashi, T.; Sutherland, S.C.; Chipman, D.W.; Goddard, J.G.; Ho, C.; Newberger, T.; Sweeney, C.; Munro, D.R. Climatological distributions of $\mathrm{pH}, \mathrm{pCO}_{2}$, total $\mathrm{CO}_{2}$, alkalinity, and $\mathrm{CaCO}_{3}$ saturation in the global surface ocean, and temporal changes at selected locations. Mar. Chem. 2014, 164, 95-125. [CrossRef]

60. Jury, C.P.; Thomas, F.I.M.; Atkinson, M.J.; Toonen, R.J. Buffer capacity, ecosystem feedbacks, and seawater chemistry under global change. Water 2013, 5, 1303-1325. [CrossRef]

61. Cai, W.-J.; Huang, W.-J.; Luther, G.W.; Pierrot, D.; Li, M.; Testa, J.; Xue, M.; Joesoef, A.; Mann, R.; Brodeur, J.; et al. Redox reactions and weak buffering capacity lead to acidification in the Chesapeake Bay. Nat. Commun. 2017, 369, 1-12. [CrossRef] [PubMed]

62. Koolivand, A.; Rajaei, M.S.; Ghanadzadeh, M.J.; Saeedi, R.; Abtahi, H.; Godini, K. Bioremediation of storage tank bottom sludge by using a two-stage composting system: Effect of mixing ratio and nutrients addition. Bioresour. Technol. 2017, 235, 240-249. [CrossRef]

63. Harvey, H.W. The Chemistry and Fertility of Sea Waters; Cambridge University Press: London, UK, 1957; p. 248.

64. Rozen, Y.; Belkin, S. Survival of enteric bacteria in seawater. FEMS Microbiol. Rev. 2001, 25, 513-529. [CrossRef]

65. Booth, I.R. Regulation of cytoplasmic pH in bacteria. Microbiol. Rev. 1985, 49, 359-378. [CrossRef] [PubMed]

66. Padan, E.; Bibi, E.; Ito, M.; Krulwich, T.A. Alkaline pH homeostasis in bacteria: New insights. Biochim. Biophys. Acta Biomembr. 2005, 1717, 67-88. [CrossRef]

67. Borah, D.; Yadav, R.N.S. Optimization of BH medium for efficient biodegradation of diesel, crude oil and used engine oil by a newly isolates B. cereus strain DRDU1 from an automobile engine. Biotechnology 2014, 13, 181-185. [CrossRef]

68. Strynar, M.; Sen, D.; Weaver, R.W. Nitrogen and phosphorus for growth of oil-degrading microorganisms in seawater. Bioremediat. J. 1999, 3, 85-91. [CrossRef]

69. Yakimov, M.M.; Giuliano, L.; Gentile, G.; Crisafi, E.; Chernikova, T.N.; Abraham, W.R.; Lünsdorf, H.; Timmis, K.N.; Golyshin, P.N. Oleispira antarctica gen. nov., sp. nov., a novel hydrocarbonoclastic marine bacterium isolated from Antarctic coastal sea water. Int. J. Syst. Evol. Microbiol. 2003, 53, 779-785. [CrossRef] [PubMed]

70. Bers, A.V.; Momo, F.; Schloss, I.R.; Abele, D. Analysis of trends and sudden changes in long-term environmental data from King George Island (Antarctica): Relationships between global climatic oscillations and local system response. Clim. Chang. 2013, 116, 789-803. [CrossRef]

71. Vaughan, D.; Marshall, G.; Connolley, W.; Parkinson, C.; Mulvaney, R.; Hodgson, D.; King, J.; Pudsey, C.; Turner, J. Recent rapid regional climate warming on the Antarctic Peninsula. Clim. Chang. 2003, 60, 243-274. [CrossRef]

72. Turner, J.; Overland, J. Contrasting climate change in the two polar regions. Polar Res. 2009, 28, 146-164. [CrossRef]

73. Choudhry, I. Antarctic Treaty Consultative Meeting (ATCM) XLII/Committee for Environmental Protection (CEP) XXII. Polar J. 2019, 9, 476-477. [CrossRef]

74. Turner, J.; Barrand, N.E.; Bracegirdle, T.J.; Convey, P.; Hodgson, D.A.; Jarvis, M.; Jenkins, A.; Marshall, G.; Meredith, M.P.; Roscoe, H.; et al. Antarctic climate change and the environment: An update. Polar Rec. 2014, 50, 237-259. [CrossRef]

75. Convey, P.; Peck, L.S. Antarctic environmental change and biological responses. Sci. Adv. 2019, 5, eaaz0888. [CrossRef]

76. Clarke, A.; Murphy, E.J.; Meredith, M.P.; King, J.C.; Peck, L.S.; Barnes, D.K.; Smith, R.C. Climate change and the marine ecosystem of the western Antarctic Peninsula. Philos. Trans. R. Soc. B 2007, 362, 149-166. [CrossRef]

77. Rodríguez-Blanco, A.; Duval, A.; Pelletier, E.; Delille, D.; Ghiglione, J.F. Effects of temperature and fertilization on the structure of total versus active bacterial communities from sub-Antarctic seawater exposed to crude oil and diesel fuel. Polar Res. 2013, 32, 18521. [CrossRef]

78. Nedwell, D.B. Effect of low temperature on microbial growth: Lowered affinity for substrates limits growth at low temperature. FEMS Microbiol. Ecol. 1999, 30, 101-111. [CrossRef] [PubMed]

79. Leahy, J.G.; Colwell, R.R. Microbial degradation of hydrocarbons in the environment. Microbiol. Rev. 1990, 54, 305-315. [CrossRef] [PubMed]

80. Speight, J.G. Industrial inorganic chemistry. In Environmental Inorganic Chemistry for Engineers; Speight, J.G., Ed.; CD\&W Inc.: Laramie, WY, USA, 2017; Chapter 3; pp. 111-169. [CrossRef]

81. Kirchman, D.L.; Morán, X.A.; Ducklow, H. Microbial growth in the polar oceans-Role of temperature and potential impact of climate change. Nat. Rev. Microbiol. 2009, 7, 451-459. [CrossRef]

82. Head, I.M.; Jones, D.M.; Röling, W.F. Marine microorganisms make a meal of oil. Nat. Rev. Microbiol. 2006, 4, 173-182. [CrossRef] 
83. Marietou, A.; Chastain, R.; Beulig, F.; Scoma, A.; Hazen, T.; Bartlett, D. The effect of hydrostatic pressure on enrichments of hydrocarbon degrading microbes from the Gulf of Mexico following the Deepwater Horizon oil spill. Front. Microbiol. 2018, 9, 808. [CrossRef]

84. Hazen, T.C.; Dubinsky, E.A.; DeSantis, T.Z.; Andersen, G.L.; Piceno, Y.M.; Singh, N.; Jansson, J.K.; Probst, A.; Borglin, S.E.; Fortney, J.L.; et al. Deep-sea oil plume enriches indigenous oil-degrading bacteria. Science 2010, 330, 204-208. [CrossRef]

85. Valentine, D.L.; Kessler, J.D.; Redmond, M.C.; Mendes, S.D.; Heintz, M.B.; Farwell, C.; Hu, L.; Kinnaman, F.S.; Yvon-Lewis, S.; Du, M.; et al. Propane respiration jump-starts microbial response to a deep oil spill. Science 2010, 330, 208-211. [CrossRef] [PubMed]

86. Dubinsky, E.A.; Conrad, M.E.; Chakraborty, R.; Bill, M.; Borglin, S.E.; Hollibaugh, J.T.; Mason, O.U.; Piceno, Y.M.; Reid, F.C.; Stringfellow, W.T.; et al. Succession of hydrocarbon-degrading bacteria in the aftermath of the Deepwater Horizon oil spill in the Gulf of Mexico. Environ. Sci. Technol. 2013, 47, 10860-10867. [CrossRef]

87. Kwapisz, E.; Wszelaka, J.; Marchut-Mikolajczyk, O.; Bielecki, S. The effect of nitrate and ammonium ions on kinetics of diesel oil degradation by Gordonia alkanivorans S7. Int. Biodeterior. Biodegrad. 2008, 61, 214-222. [CrossRef]

88. Mukherjee, A.K.; Bordoloi, N.K. Biodegradation of benzene, toluene and xylene (BTX) in liquid culture and in soil by Bacillus subtilis and Pseudomonas aeruginosa strains and a formulated bacterial consortium. Environ. Sci. Pollut. Res. Int. 2012, 19, 3380-3388. [CrossRef]

89. Ferguson, S. Nitrogen cycle enzymology. Curr. Opin. Chem. Biol. 1998, 2, 182-193. [CrossRef]

90. Carswell, A.; Shaw, R.; Hunt, J.; Sánchez-Rodríguez, A.R.; Saunders, K.; Cotton, J.; Hill, P.; Chadwick, D.R.; Jones, D.L.; Misselbrook, T.H. Assessing the benefits and wider costs of different $\mathrm{N}$ fertilisers for grassland agriculture. Arch. Agron. Soil Sci. 2019, 65, 625-639. [CrossRef]

91. Urakawa, H.; Rajan, S.; Feeney, M.E.; Sobecky, P.A.; Mortazavi, B. Ecological response of nitrification to oil spills and its impact on the nitrogen cycle. Environ. Microbiol. 2019, 21, 18-33. [CrossRef] [PubMed]

92. Herbert, R. Nitrogen cycling in coastal marine ecosystems. FEMS Microbiol. Rev. 1999, 23, 563-590. [CrossRef] [PubMed]

93. Isnansetyo, A.; Getsu, S.; Seguchi, M.; Koriyama, M. Independent effects of temperature, salinity, ammonium concentration and $\mathrm{pH}$ on nitrification rate of the Ariake seawater above mud sediment. HAYATI J. Biosci. 2014, 21, 21-30. [CrossRef]

94. Vyas, T.K.; Dave, B.P. Effect of nitrogen, phosphorous and potassium fertiliser on biodegradation of crude oil by marine bacteria. Indian J. Mar. Sci. 2010, 39, 143-150.

95. Chen, Y.; Yu, B.; Lin, J.; Naidu, R.; Chen, Z. Simultaneous adsorption and biodegradation (SAB) of diesel oil using immobilized Acinetobacter venetianus on porous material. Chem. Eng. J. 2016, 289, 463-470. [CrossRef]

96. Pomeroy, L.R.; Wiebe, W. Temperature and substrates as interactive limiting factors for marine heterotrophic bacteria. Aquat. Microb. Ecol. 2001, 23, 187-204. [CrossRef]

97. Goud, B.S.; Prathibha, D. Evaluating the effect of substrate type and concentration in the biodegradation of petroleum hydrocarbons. Int. J. Agric. Environ. Biotechnol. 2017, 10, 669-674. [CrossRef]

98. Vieira, G.; Magrini, M.J.; Bonugli-Santos, R.C.; Rodrigues, M.; Sette, L.D. Polycyclic aromatic hydrocarbons degradation by marine-derived basidiomycetes: Optimization of the degradation process. Braz. J. Microbiol. 2018, 49, 749-756. [CrossRef]

99. Kanaly, R.A.; Harayama, S.; Watanabe, K. Rhodanobacter sp. strain BPC1 in a benzo[a]pyrene-mineralizing bacterial consortium. Appl. Environ. Microbiol. 2002, 68, 5826-5833. [CrossRef] [PubMed]

100. Wu, Y.; Zhu, Q.; Zeng, J.; Ding, Q.; Gong, Y.; Xing, P.; Lin, X. Effects of pH and polycyclic aromatic hydrocarbon pollution on thaumarchaeotal community in agricultural soils. J. Soil Sediment 2016, 16, 1960-1969. [CrossRef]

101. Radniecki, T.S.; Dolan, M.E.; Semprini, L. Physiological and transcriptional responses of Nitrosomonas europaea to toluene and benzene inhibition. Environ. Sci. Technol. 2008, 42, 4093-4098. [CrossRef] [PubMed] 